\title{
Gezi Parkı Protestoları ve Haber Dili: Barış Gazeteciliği Perspektifiyle Haber Analizleri
}

\author{
Tirşe ERBAYSAL FiLIBELi
}

doktora öğrencisi, galatasaray üniversitesi medya ve iletişim çalışmaları tirserbaysal@gmail.com

\begin{abstract}
Gezi Park Protests and News Language: News Analysis with Peace Journalism Perspective

At the first days of Gezi Park Protests, mostly the mainstream media didn't cover the news regarding Gezi and they violated the publics' right to freedom of information. In the light of this situation, the relation between media, political power, capital and ideology should be elaborated. According to the theory of peace journalism, aggressive and hateful discourses can polarize the society, increase conflicts and cause violence. Thus, in this study we analyze front pages of 15 newspapers between May 29 and June 24 2013, by utilizing critical discourse analysis method. Additionally, we examine the findings of semi-structured interviews carried out with 30 Turkish journalists. This study includes the debates on the structure of the news and tries to find answers on how the news should be structured towards the theory of peace journalism. Our findings and the opinions of journalists on the news language show that the media in Turkey mostly use conflictive and discriminative language.
\end{abstract}

keywords: peace journalism, news language, critical discourse analysis, Gezi Park Protests 


\section{Résumé}

\section{Le mouvement protestataire de Gezi et le langage de l'information: I'analyse des nouvelles dans une perspective du journalisme de paix}

Au début, les nouvelles sur le mouvement protestataire de Gezi n'avaient pas été publiées ou télévisées en Turquie. Les journaux nationaux et les chaînes de télévision en Turquie n'ont pas respecté au droit public de l'information. Cette situation nous amène à penser sur la relation entre les médias, le pouvoir politique et l'idéologie. Selon la théorie du journalisme de paix, les discours agressifs et les discours de haine peuvent polariser la société, augmenter les conflits et puis engendrer la violence. Dans ce travail, on examine les nouvelles publiées à la Une de 15 journaux turques du 29 Mai au 24 Juin 2013 avec la méthode d'analyse critique du discours ainsi que des entretiens (semi-structurés) avec les journalistes (30 entretiens ont été réalisés). Ce travail contient les débats sur la structure de l'information et essaie de trouver la réponse à la question suivante " comment doivent être les informations à l'égard du journalisme de paix ?". Nos conclusions et les opinions des journalistes sur la langue des nouvelles montrent que les médias en Turquie utilisent généralement une langue conflictuelle et discriminative.

mots-clés : journalisme de paix, analyse critique du discours, langage de I'information, le mouvement Gezi

\section{Öz}

Gezi'nin ilk günlerinin basında yeterince yer bulamamış olması sonucu kamunun bilgi edinme hakkının ihlal edilmesi ve sonrasında haberlerde kullanılan dil ve söylemler; bizi medya, iktidar, ideoloji üzerine düşünmeye yönlendirmektedir. Barış gazeteciliği teorisinin öngördügü üzere saldırgan, nefret içerikli söylemler toplumun kutuplaşmasına, çatışmaların artmasına ve dolayısıyla şiddete sebep olmaktadır. Buradan hareketle, bu çalışmada 15 gazetenin 29 Mayıs-24 Haziran 2013 tarihleri arasında ilk sayfalarında yer alan haberler eleştirel söylem analizi yöntemiyle incelenmekte ve 30 gazeteci ile yapmış olduğumuz yarı-yapılandırılmış görüşmeler analiz edilerek haberlerde nasıl bir dil kullanıldığı ve barış gazeteciliği bağlamında haberin nasıl olması gerektiği tartışılmaktadır. Bulgularımız ve gazetecilerin haber dili üzerine sunmuş olduğu görüşler, Türkiye'de medyanın çoğunlukla çatışmacı ve ayrımcı bir dil kullandığını göstermektedir.

anahtar kelimeler: barış gazeteciliği, eleştirel söylem analizi, haber dili, Gezi Parkı Protestoları 


\section{Giriş}

2010 yılında Tunus'ta seyyar satıcı olarak çalışan Muhammed Buazizi'nin kendini yakarak intihar etmesi, sosyal medyada hızla yayılarak demokrasi, özgürlük ve adalet arayışı içinde olan kesimlerin bir araya gelmesine vesile olmuştur. Tunus'un ardından Mısır, Libya, Suriye gibi birçok Ortadoğu ülkesinde demokrasi adına ayaklanmalar başlamıştır. Çatışmalara gebe olan kırılgan siyasal, sosyal, ekonomik, kültürel ve dini ortamlara sahip Ortadoğu ülkelerinde yaşanan bu ayaklanmalar tüm negatif sonuçlarına rağmen örgütlenme açısından bir örnek teşkil etmiş ve demokrasinin kalbinde, Amerika'da, New York'ta gerçekleşen Occupy Wall Street ile Arap Baharı yer yer bir arada anılmıştır. İspanya'da, ${ }^{1}$ Portekiz'de ${ }^{2}$ ve Ortadoğu'da başlayan protestoların etkilerinin görüldüğü Occupy, Wallstreet'in önünde "biz \%99'uz" sloganıyla gerçekleştirilen eylem ile tüm dünya tarafından duyulmuş ve ABD'den Yunanistan'a ${ }^{3}$, Yunanistan'dan Türkiye'ye kadar pek çok ülkede çoğu zaman barışçl bir sivil itaatsizlik eylemi olarak başlayan hareketler Occupy ile adlandırımıştır (Castells 2012; Chomsky 2013; Zizek 2013; Mitchell, Hartoug, Taussing 2013).

Hareketlerin Türkiye'deki örneğini 27 Mayıs 2013'te başlayan Gezi Parkı Protestoları/Gezi Direnişi/Occupy Gezi ${ }^{4}$ oluşturmuştur. Gezi, bir çevre hareketi olarak başlamış, farklı toplumsal kimliklerin protestolara dâhil olması ile bir işgal hareketine dönüşmüş ve nihayetinde özgürlük ve demokrasi adına yaşanan tüm haksızlıklara karşı birleştirici lidersiz ortak bir hareket olarak varlığını sürdürerek Türkiye'nin siyasi ve toplumsal tarihindeki en büyük toplumsal hareketlerden bir tanesine dönüşmüştür.

Gezi'yi barış gazeteciliği alanındaki çalışmamız için eşsiz kılan iki önemli unsur bulunmaktadır. Öncelikle, barış gazeteciliğinin sadece sıcak çatışma ve savaş alanlarında uygulanan bir gazetecilik pratiği olmamasından barış gazeteciliğinin

115 Mayıs 2011'de İspanya'da ekonomik kriz sebebiyle işsiz kalan kimseler hükümete karşı protestolar düzenlemeye başlamıştır. "Indignants Movement" yani "Öfkeliler Hareketi" olarak bilinen bu protestolar başka ülkelerde aynı sebeplerden dolayı gerçekleşen pek çok protestoya ilham vermişstir. $15 \mathrm{M}$ Hareketi olarak da bilinen İspanya Protestoları'nın birinci senesinde "indignants" olarak anılan protestocular dünyanın pek çok şehrinde aynı anda gerçekleşen yürüyüşler düzenlemişlerdir.

212 Mart 2011'de işsizlik ve ekonomik krize karşı Portekiz'de protestolar başlamıştır. İspanya'daki protestolara ilham vermiştir.

32010 yılında İspanya ve Protekiz'de olduğu gibi ekonomik kriz ve onun yol açmış olduğu işsizlik sebebiyle başlayan hareketlerdir. İspanya'daki protestoların ardından "Indignants Hareketi" nden etkilenmiş ve Yunan Indignants Hareketi'ne dönüşmüştür.

4 Gezi Parkı'nda başlayan ve T.C. İç İşleri Bakanlığı'nın yapmış olduğu açıklamaya göre Türkiye'deki 81 ilin 79'unda süregelen protestolara 2.5 milyon kişi katılmıştır. Türkiye'nin farkı illerinden ve farklı kesimlerinden insanların katılmış olduğu protestolar "eylem", "direniş", "işgal", "protesto" vb. şekillerde tanımlanmıştır. Çalışmamızda Gezi Parkı'nda başlayan ve tüm ülkeye yayılan protestolar birden çok protestoyu ifade etmesi ve bir yerde başlamasına rağmen o bölgeyi sembolize ederek pek çok farkı şehirde var olması sebebiyle "Gezi Parkı Protestoları" veya kısaca "Gezi" olarak ifade edilmektedir. 
toplumsal, siyasal, kültürel vb. her türlü çatışmanın haberleştirilmesini temellendiren bir teori ve gazetecilik pratiği olmasından yola çıkılarak; toplumun farklı kesimlerinden çok sayıda insanın bir araya geldiği bir hareket olan Gezi'nin barış gazeteciliği için eşsiz bir örneklem oluşturduğu düşünülmüştür. İkinci olarak, o dönemde uygulanan gazetecilik pratiklerinin medyanın ekonomi-politiği açısından çokça tartışılmış olması, toplumun bilgi edinme hakkından mahrum bırakılmasıyla temel gazetecilik mesleki kodlarının dahi uygulanmamış olması ve eylemcilerin ana akım medyaya karşı olan tepkileri ve hak arayışları Gezi'nin barış gazeteciliği üzerinden düşünülmesini gerektirmektedir.

Gezi'nin ilk günlerinde yaşananları neredeyse hiçbir televizyon kanalı haber yapmamıştır. CNN Türk 'Penguen Belgeseli' yayınlarken, NTV 'Hitler Belgeseli' yayınlamıştır. Sosyal medyada penguen medyası gibi kavramlar kendini gösterirken, insanlar kendi haber ağlarını oluşturmuş ve Gezi'de Çapul TV devreye girmiştir. Yazılı basının neredeyse tamamı sansüre, oto-sansüre veya sipariş haberlere teslim olmuştur. Dönemin başbakanı Recep Tayyip Erdoğan'ın Afrika gezisi dönüşünde havalimanında yapmış olduğu konuşmayı yedi gazete (Yeni Şafak, Habertürk, Sabah, Bugün, Türkiye, Zaman ve Star) "Demokratik taleplere canımız feda" manşeti ile vermiştir. Medyanın görevini yerine getirmemesi çatışmaları durdurmak yerine yeni çatışmalara sebep olmuştur. Insanlar ana akım medyayı ve medya patronlarının başka alanlardaki yatırımlarını da protesto etmeye başlamışlardır. Ekonomi de protestolardan kötü yönde etkilenmiştir (Balcı, 2013). Sonuç olarak geleneksel medya sadece barış gazeteciliği adına değil temel gazetecilik pratikleri adına da oldukça kötü bir sınav vermiştir.

Bianet'in 27 Mayıs-30 Eylül Bi̇A Medya Gözlem Raporu'na göre Gezi döneminde 153 gazeteci haber peşinde koşarken yaralanmış, en az otuz dokuz gazeteci gözaltına alınmış, bunlardan üç tanesi tutuklanmıştır (Gülcan, 2013a). Temmuz-Ağustos-Ekim 2013 tarihli BỉA Medya Gözlem ve Ifade Özgürlüğü Raporu'nda yer alan bilgilere göre ise en az kırk sekiz gazeteci bizzat polis tarafından darp edilerek yaralanmıştır (Gülcan, 2013b). Bianet ${ }^{\prime}$ in verilerine göre Gezi ile ilgili tutumları çalıştıkları yayın kuruluşlarının Gezi'ye yaklaşımlarıyla çelişen en az yirmi iki gazeteci, bir programcı, bir akademisyen bu süreçte istifa etmiştir. On dört gazeteci ve altı akademisyen ise işten çıkartılmıştır (Gülcan, 2013a). Türkiye Gazeteciler Cemiyeti'nin yapmış olduğu açıklamaya göre ise o dönemde en az yüz gazeteci işten ayrılmaya zorlanmıştır (2013). Gezi'nin üzerinden yedi aya yakın bir süre geçtikten sonra 17 Aralık Yolsuzluk Operasyonu gerçekleştirilmiştir. Gezi Parkı'nın ve bu operasyonun yankıları Türkiye'de süregelirken 20 Mart 2014'te Twitter'a, 27 Mart 2014'te de Youtube'a erişim engellenmiştir. Hem Gezi sırasındaki gazetecilik pratikleri, hem de basın özgürlüğüne ilişkin yasaklar ve tutuklamalar nedeni ile Türkiye, Sınır Tanımayan Gazeteciler'in hazırladığı Dünya Basın Özgürlüğü raporunda 2013 yılında 179 ülke arasında, 2014 yılında ise 180 ülke arasında 154. sırada yer almıştır (Sınır Tanımayan Gazeteciler, 2014). Bununla birlikte Freedom House Örgütü'nün basın özgürlügü konusundaki raporunda Türkiye 2013 yılında "kısmen özgür" kategorisinde yer alırken 2014 
raporunda "özgür değil" kategorisinde yer almıştır. Freedom House'un Mayıs 2013 - Mayıs 2014 tarihleri arasındaki durumu gösterdiği internet raporunda ise Türkiye "kısmen özgür" kategorisine girmiştir.

Insanların haber alma hakkı, onların demokratik var oluşlarının olmazsa olmaz bir parçasıdır. Bu eksende medya, iktidar, ideoloji ve sermaye ilişkilerinin demokrasiye etkileri incelendiğinde, insanların haber alma hakkını çoğunlukla kullanamadığı ve söylemin düzenine ${ }^{5}$ ayak uydurmak durumunda kaldığı gözlemlenmektedir. Öte yandan gelişen teknolojiler sayesinde yeni medya geleneksel medyanın iktidar, ideoloji ve sermayeden doğan söylemlere hapsolmuşluğuna karşı bir özgürlük alanı yaratmaktadır. Ancak kamusal katılımın tam anlamıyla sağlanabilmesi için en yaygın araç hâlâ gazete ve televizyonlardır. Bu bağlamda kitle medyasının en temel görevi olan haber verme işlevini nasıl ve ne şekilde yerine getirdiğini tartışmak gerekmektedir.

Türkiye Gazeteciler Cemiyeti'nin Hak ve Sorumluluk Bildirgesi'nde gazetecinin haklarının, halkın haber alma ve ifade özgürlüğünün; meslek ilkelerinin ise dürüst ve doğru iletişimin temeli olduğu söylenmektedir. Bildirgenin C maddesine göre;

"Gazeteci, basın özgürlügünü, halkın doğru haber alma, bilgi edinme hakkı adına dürüst biçimde kullanır. Bu amaçla her türlü sansür ve otosansürle mücadele etmeli, halkı da bu yönde bilgilendirmelidir. Gazetecinin halka karşı sorumluluğu, başta işverenine ve kamu otoritelerine karşı olmak üzere, öteki tüm sorumluluklardan önce gelir."

Avrupa İnsan Hakları Sözleşmesi'nin ifade özgürlüğü üzerine olan onuncu maddesinde herkesin görüşlerini açıklama ve anlatım özgürlüğüne sahip olduğu ifade edilmekte ve bu hakkın, kanaat özgürlüğü ile kamu otoritelerinin müdahalesi ve ülke sınırları söz konusu olmaksızın haber veya fikir alma ve verme özgürlüğünü de içerdiği belirtilmektedir.

Türkiye'deki basın özgürlüğüne ilişkin tüm bu veriler, TGC'nin Hak ve Sorumluluk Bildirgesi'nin ve Avrupa İnsan Hakları Sözleşmesi'nin aksine haber verme ve dolayısıyla haber alma hakkının Gezi döneminde ihlal edildiğini göstermektedir. Bunun yanı sıra, medya, iktidar ve ideoloji arasındaki ilişkiye eleştirel bir perspektif ile bakıldığında, medyanın tarih boyunca iktidarın ideolojik ve hegemonik söylemlerini yaymak için kusursuz bir araç olarak kullanıldığı görülmektedir. 6

5 Foucault, (1987) söylemin bir düzeni olduğunu ve dünyanın her yerinde insanların doğdukları andan itibaren doğdukları yerdeki düzene ayak uydurmak üzere disiplin, ceza ve ödül yolları kullanılarak yetiştirildiğini ifade etmektedir.

6 Louise Althusser'in ifadesiyle haberleşme alanında devletin ideolojik aygıtı olma görevini üstlenen medya erk sahiplerine bu konuda hizmet etmektedir. Althusser devletin ideolojik aygıtlarının her zaman üretim ilişkilerinin yeniden üretimi, yani kapitalist sömürü ilişkilerinin yeniden üretimi hedefine yöneldiğini ve haber aygıtının tüm yurttaşları günlük milliyetçilik, şovenizm, liberalizm, ahlakçlık ve benzeri dozlar ile beslediğini ifade etmektedir (2003, s. 169-179). 
Bu makalede Gezi dönemindeki gazetecilik pratikleri; on beş ulusal gazetenin 29 Mayıs-24 Haziran 2013 tarihleri arasında ilk sayfalarında yer alan haberlerinin eleştirel söylem analizi yöntemi kullanılarak analiz edilmesiyle elde edilen veriler ve otuz gazeteci ile gerçekleştirmiş olduğumuz yarı-yapılandırılmış görüşmelerden elde etmiş olduğumuz bulgular değerlendirilerek, genel geçer gazetecilik pratiklerine ve mesleki kodlara alternatif bir pratik sunan barış gazeteciliği kuramı üzerinden haber dili ve barış söylemi bağlamında ele alınmaktadır.

\section{Barış Gazeteciliği ve Haberin İnşasında Barış Dili}

Susan Sontag'ın "Başkalarının Acısına Bakmak" kitabında da belirttiği üzere savaşlar ve çatışmalar hepimizin oturma odalarında sükûnet içinde seyredilip dinlenen görüntü ve seslere dönüşmüşlerdir (2005, s. 17). Teknolojik gelişmelere paralel olarak ilerleyen enformasyon teknolojilerinin kullanımının yaygınlaşması ile savaşlar ve çatışmalar sıradan insanın hayatının bir parçası haline gelmiştir. Çatışmaların ve şiddetin bu denli yoğun tüketilmesi onları olağanlaştırmış, normalleştirmiştir. Nitekim şiddetin normalleşmesi 'barış'ın konuşulacağı ortamların yaratılmasını güçleştirmektedir. Bu nedenle barışın konuşulması için barış üzerine ve tabii ki savaşı ve çatışmayı topluma aktaran gazeteciler üzerine düşünmek medya ve gazetecilik araştırmaları açısından önem arz etmektedir.

Barış gazeteciliği kavramını anlayabilmek için öncelikle 'barış'ı tanımlamamız gerekmektedir. Barış kavramı siyaset bilimciler, dil bilimciler, barış teorisyenleri ve sosyologlar tarafından farklı şekillerde tanımlanmıştır. "Barış" kelimesi en basit şekliyle Türk Dil Kurumu tarafından uyum, karşııklı anlayış ve hoşgörü ile oluşturulan ortam olarak tanımlanmaktadır. Galtung 'barış'ı şiddetsizlik kavramıyla ifade etmektedir ve barışın 'şiddetsizlik + yaratıcılık' formülü ile sağlanabileceğini ileri sürmektedir. Galtung, barışın tesisinde duyguların itici bir güç olduğunu, entelektüelliğin ise kullanılan bir araç olduğunu ifade ederek barış çalışmalarında empati, yaratıcılık ve şiddetsizliğin son derece önemli unsurlar olduğunu söylemektedir (2009, s. 222). Sevda Alankuş, Galtung'un çalışmalarından yola çıkarak Martin Luther King'in "Savaş, yaratıcılığın anti-tezidir" söylemine bir gönderme yapmaktadır ve 'Barış da, yaratıcılıktır' diyerek günümüzde norm haline gelmiş klişeleri sadece zaman azlığıyla açıklanamayacak gerekçelerle kullanmaya devam eden gazeteci yerine, bunları kıracak yaratıcı bir gazeteci modeline gereksinim duyulduğunu dile getirmektedir (aktaran Vardar, 2013). Alankuş, Barış Gazeteciliği El Kitabı'nda barışa, sosyal adaleti engelleyecek insanların önünde engel olarak duran yapısal ve kültürel şiddeti azaltacak politikaları ifade eden pozitif bir anlam atfettiklerini belirtmektedir. Bu bağlamda, barış gazeteciliğinin sınırlarını genişletmek gerektiğini söyleyen Alankuş, hak odaklı barış gazeteciliği kavramını ortaya atmaktadır ve barış gazeteciliğinin, her türlü gerilim, çatışma ve çoklu karşıtlıkların şiddet kışkırtıcılığı yapmadan, adil bir barışın sağlanması ve sürdürülmesi yönünde 'öteki' merkezli bir etik çerçevesinde haberleştirilmesi olduğunu belirtmektedir (2016, s. 30-31). 
Annabel McGoldrick ve Jake Lynch barış gazeteciliğinin editörler ve muhabirlerin neyi/nasıl haber yapacağı ile ilgili olduğunu belirterek, kavramın çatışmalar konusunda şiddet içermeyen yanıtların değerlendirildiği ve toplum için fırsatların yaratıldığı haberlerin seçimi ile alakalı olduğunu söylemektedirler (2005, s. 5). Özetle, barış gazeteciliği kazananın ve kaybedenin olduğu habercilik yerine taraflar arasında dengenin sağlandığı, gerçek odaklı haberciliği esas alan, toplumsal barışın sağlanması için yaratıcı çözümler arayan, lider değil insan/ toplum odaklı habercilik yaparak sıradan insanlara ses veren, nefret dili ve ayrımcı dil yerine barış dilinin kullanımına özen gösteren bir gazetecilik pratiğini ifade etmektedir (Galtung ve Lynch, 2010; Lynch and McGoldrick, 2005).

Richard Lance Keeble 'barış gazeteciliği'ni devrimsel bir siyasal pratik olarak tanımlamaktadır (2010, s. 50). Jean Lee C. Patindol ise barış gazeteciliği kavramını 'çatışmaya duyarlı gazetecilik'7 kavramıyla betimlemektedir (2010, s. 199-200).

Dov Shinar, barış gazeteciliğinin, çatışmaları sorumlu ve bilinçli şekilde haberleştirmenin normatif biçimi olduğunu söyleyerek, barış gazeteciliğinin uzlaşmayı, barışı sağlamayı, barışı korumaya katkıda bulunmayı ve medya patronlarının, reklamcıların, profesyonellerin ve izleyicilerin savaş ve barışa karşı yaklaşımlarını değiştirmeyi amaçladığını ifade etmektedir. Barış gazeteciliğinin 'iyi haberleri' vermek anlamına gelmediğini ifade eden Shinar, barış haberciliğinin geleneksel haber yapma yöntemleri karşısında, çatışmaların daha adil şekilde haberleştirilmesi anlamına geldiğini söylemektedir (2007, s.165-166).

İnceoğlu ve Sözeri barış gazeteciliğinin medyanın çarpıtılmış, eksik, dramatize edilmiş ve zaman zaman paranoyaya varan komplo teorileri ile donatılmış, geçmişte yaşanan acı, felaket, nefret ve düşmanlığı kurcalayan haberleri gündemde tutmaktan ziyade, barışa ve çözüme odaklı, insan hakları ve demokrasiden taraf, ayrımclık ve kutuplaşmayı körüklemeyen bir tavır sergilemesi gerektiğini ve en önemlisi bunu yaparken yurttaşın bilgi edinme hakkını ihlal etmemesi gerektiğini belirtmektedirler (2012, s. 25).

Barış gazeteciliği üzerine düşünüldüğünde barışın tam tersi olan çatışma ve çatışmadan doğan şiddet konusuna da değinmek gerekmektedir. Zira barış gazeteciliği çoğunlukla çatışmanın giderilmesi ve şiddetin önlenmesi ile açıklanmaktadır.

Galtung ve Lynch çatışmayı çeşitli tarafların amaçlarının birbirinin yoluna çıkması olarak ifade ederek çatışmanın şiddete neden olabileceğinin altını çizmektedirler (2010, s. 4). Lynch ve Goldrick çatışmayı, birbiri ile bağdaşmayan

7 Filipinli araştırmacı, ülkesinde "barış gazeteciliği" kavramının kafa karıştıııcı bir anlam ifade ettiğini ve bu sebeple kavramı daha anlaşılır kılmak için "çatışmaya duyarlı gazetecilik" kavramının kullanıldığını ifade etmektedir. 
amaçları, intiyaçları, ve çıkarları olan iki veya daha fazla grup arasındaki ilişki olarak tasvir etmektedir (2005, s. 34). McGoldrick ve Lynch şiddeti; vurma, ateş etme, bombalama gibi sadece fiziksel teması gerektiren şiddet olarak değil, aynı zamanda dilin kötü kullanımını da içeren psikolojik şiddet olarak tanımlamaktadır (2005, s. 59). Çatışmaya ve çatışmadan doğan şiddete ilişkin tüm bu tanımlamalardan yola çıkarak sormamız gereken soru, gazetecilerin çatışmanın ve şiddetin bu anlamlarına hakim bir şekilde gazetecilik yapıp yapmadığıdır. Zira görüşme yaptığımız gazetecilerin büyük bir bölümü barış gazeteciliği üzerine düşündükleri zaman sadece savaş zamanında yapılan gazetecilik algısına sahip olduklarını ifade etmektedirler. Oysa barış gazeteciliği sadece fiziki değil, sosyal, kültürel, dini, cinsel kimliğe yönelik, siyasal vb. tüm çatışmaların çözüme kavuşturulmasına yönelik bir hedef sunmakta, çatışma ve şiddetten uzak bir dil kullanarak psikolojik şiddetin de önüne geçilmesini amaçlamaktadır.

Johan Galtung barış gazeteciliğinin, ve onun karşısında konumlandırdığı savaş gazeteciliğinin farklarını karşılaştırmalı bir tablo ile özetlemiştir. Buna göre barış gazeteciliği barış/uzlaşma odaklı, gerçek odaklı, halk odaklı ve çözüm odaklıdır. Öte yandan, barış gazeteciliğinin karşısında yer alan savaş gazeteciliği gazetelerin ve televizyonların pek çoğunun yıllardır uyguladığı şiddetin daha fazla sattığını öngören gazetecilik pratiğini tasvir etmektedir (Lynch \& McGoldrick; 2005 , s. 6). Ingilizce'de "If it bleeds, it leads" olarak yerleşmiş olan, Türkçe'de kan varsa haberin manşet olabileceği anlamına gelen yaygın söylem de bu gazetecilik mantığına aittir.

Barış gazeteciliğinin şiddetin haberleştirilmesi konusundaki bakış açısı birtakım tartışmaları gündeme getirmektedir, çünkü gazetecinin görevi haber yapmaktır ve şiddet bir haberdir. McGoldrick ve Lynch bu konuda barış gazeteciliği standartlarının yanlış anlaşıldığına vurgu yaparak, şiddetin haberleştirilmemesi değil şiddetin nasıl haberleştirildiğinin önemli olduğunu ifade etmektedirler (2005, s. 57). Bu noktada Türkiye'de şiddetin ve çatışmaların nasıl haberleştirildiği sorusunu sorarak, yakın tarihindeki en büyük toplumsal harekete yani Gezi'ye ilişkin haberleri incelemek, Türkiye'deki gazetecilik pratiklerini anlamamız için son derece önemlidir.

Gezi, başlayıp, sona eren bir süreci ya da olayı değil, üzerinden üç seneyi aşkın bir süre geçmiş olmasına rağmen hâlâ haberleri yapılan ve etkileri izlenen bir süreci ifade etmektedir. Gezi sırasında ortaya çıkan toplumsal çatışma ve ayrışmanın haber dilindeki izleri ise hala görülmektedir. Bu nedenle Gezi barış gazeteciliği üzerine yapacağımız bir çalışma için son derece önemli bir araştırma evreni oluşturmaktadır.

\section{Barış Gazeteciliği Prensipleri, Gezi ve Haber Dili}

Geçtiğimiz yüzyılın insanlık tarihindeki en ölümcül ve en şiddetli yüzyıl olduğunu ve bu yüzyllın dili olan savaş ve nefretin tüm dünya tarafından çok 
iyi öğrenildiğini dile getiren McGoldrick ve Lynch (2001), Galtung'un barış gazeteciliği kavramı üzerine kurmuş olduğu teoriyi geliştirerek çatışma ve barış haberlerinin inşasında küresel bir standart belirlemek için birtakım ilkeler ortaya koymuşlardır (2005, s. 28-31). Söz konusu ilkelere ${ }^{8}$ göre öncelikle bir çatışmayı sadece iki tarafın çatışması gibi göstermekten kaçınmak gerekmektedir. Çünkü iki taraflı çatışmalarda çoğunlukla bir kazanan ve bir kaybeden olmaktadır. Onun yerine kimlerin çatışmaya taraf olduğunu sorarak çatışmaya taraf olan ana gruplar içerisindeki küçük grupları tespit etmek ve bu grupların amaçlarını, intiyaçlarını ve çıkarlarını dile getirmek gerekmektedir. Bunu yaparken 'ben' ve 'öteki' gibi keskin ayrımlar yapmaktan kaçınmak ve ötekini kendinde aramak gerekmektedir. Çünkü keskin ayrımlar tarafların 'tehdit' ya da 'düşman' olarak görülmesine ve şiddetin haklılaştırılmasına sebep olabilmektedir.

Çatışmanın sadece şiddetin meydana geldiği zamanda ve yerde var olduğunu düşünerek haber yapmaktan kaçınarak, o andaki ve gelecekteki insanlar için çatışmanın sonuçlarının ve bağlantılarının izleri sürülerek, çatışmanın paydaşları, kimin ne kazandığı, kimin çatışmalardan etkilendiği, gelecekte ne olacağı, ne gibi dersler çıkarıldığı sorularak haber yapılmalıdır. Bununla birlikte çatışmalara ilişkin haberler yapııırken fikirleri ve iddiaları olgusal doğrularmış gibi göstermekten kaçınarak, izleyiciye/okura kimin ne söylediğini iletmek önemlidir. Zira propaganda olgusal doğrular ile işlemektedir ve çatışma dönemlerinde propagandadan kaçınmak mühimdir.

Gazeteciler bir şiddet eylemini ya da şiddet politikasını sadece görünür etkileri açısından değerlendirmemelidir. Bunun yerine, psikolojik tahribat ve travmanın uzun dönemli sonuçları gibi, şiddete maruz kalanların gelecekte başka insanlara ya da bir grup olarak başka gruplara veya başka ülkelere şiddet uygulayacağı ihtimali gibi, şiddetin görünmeyen etkileri hakkında da haber yapma yollarını aramalıdır. Gazeteciler, şiddet eylemlerinin ve vahşetin haberleştirilmesi ile intikam ve ceza duygularına çağrı yapmak yerine, şiddetin insanlar üzerindeki etkilerine dair haber yapmalıdır ve bunu yaparken şiddetin sorumlusu olarak birisini suçlamaktan kaçınarak, ortak sorunların hiçbir tarafın arzulamadığı sonuçlara yol açabileceğini göstermeye çalışmalıdır.

Haber yaparken tarafları, sadece liderlerinin ağzından bildik talepleri ya da pozisyonları içeren açıklamalarla tanımlamaktan kaçınarak, 'lider odaklı haber' yapmak yerine gündelik hayatta insanların çatışmadan nasıl etkilendiğini, insanların neyin değişmesini istediklerini, arzulanan değişikliklerin gerçekleşmesinin tek ya da en iyi yolunun liderlerin vurguladığı yol olup olmadığını sorgulayan haberler yapmak gerekmektedir.

8 McGoldRick ve Lynch'in ortaya koymuş olduğu 17 ilkenin içerisinden haber dili ve söylem ile ilgili olan ilkeler özetlenerek açıklanmıştır. Illkelerin tamamına McGoldrick ve Lynch'in Peace Journalism kitabından ve Mine Gencel Bek'in özetleyerek Türkçe'ye çevirdiği ilkelere Süleyman İrvan'ın kaleme aldığı Barış Gazeteciliği makalesi üzerinden ulaşılabilir. 
Gazeteciler sadece bir tarafın acılarına, korkularına ve üzüntülerine odaklanmadan, tüm tarafların acılarına, korkularına ve şikayetlerine yer vererek; 'caniler' ve 'kurbanlar' şeklinde ayrım yapmaktan kaçınmalıdır. Unutmamak gerekir ki haberin üretilmesinde kullanılan dil çok önemlidir. Bu sebeple kurbanlaştırıcı sözcükler kullanmaktan kaçınmak ve insanların neleri yaptıklarını ve neleri yapabileceklerini haberleştirmek gerekmektedir. Dilin kullanılması konusunda dikkat edilmesi gereken bir diğer konu ise, insanlara ne olduğu anlatılırken trajedi, soykırım, katliam, suikast gibi değer yüklü sözcüklerin kullanımında özen gösterilmesi ve saldırgan, zalim, terörist, aşırı, köktendinci vb. şeytanlaştırıcı sıfatları kullanmaktan kaçınılması gerektiğidir.

Tüm bu ilkeler ışığında çalışmamızda "Gezi sırasında nasıl bir haber dili kullanıldığı" sorusu sorulmuş ve "nasıl bir haber dili kullanılması gerektiği" sorusuna yanıt aranmıştır.

\section{Araştırma Yöntemi}

Çalışmamız ekseninde, gazetelerin kullanmış oldukları dil ve kelime frekansları ile iktidara olan mesafelerinin tespit edilebileceği, gazetelerin tamamında ayrıştırıcı/kutuplaştırıcı dil kullanımlarına rastlanacağı, haber aktarılırken büyük çoğunlukla lider odaklı habercilik yapılmış olacağı, yapmış olduğumuz görüşmelerde ise gazetecilerin kullanılan dil ve kullanılması gereken dil arasındaki ayrımın bilincinde olacağı varsayımlarından hareket edilerek, 29 Mayıs-24 Haziran tarihleri arasında on beş gazetenin ilk sayfalarında yer alan (Akşam, BirGün, Cumhuriyet, Habertürk, Hürriyet, Milliyet, Posta, Radikal, Sabah, Sözcü, Star, Taraf, Yeni Akit, Yeni Şafak, Zaman) haberler eleştirel söylem analizi yöntemi ile incelenmiştir. Nvivo Nitel Analiz Programı kullanılarak, on beş gazetenin 27'şer günlük ilk sayfaları, sisteme yüklenmiş ve ilk sayfalarda yer alan haberler ve görseller, kelime frekanslarına, haber fotoğraflarına ve söylemlere yönelik olarak oluşturmuş olduğumuz kategoriler altında derlenerek analiz edilmiştir. Haber dili konusunda her gazete için kullanılan kelime ve kelime öbekleri belirlenmiş ve bu ifadelerin kullanım frekansları tek tek hesaplanarak her gazete için ayrı birer tablo oluşturulmuştur.

Bunun yanı sıra kartopu yöntemiyle yazılı ve görsel basından otuz gazeteciye ulaşılmış ve Gezi dönemindeki habercilik pratikleri ve barış gazeteciliği üzerine yarı-yapılandırılmış görüşmeler gerçekleştirilmiştir. Görüşmelere ilk olarak Gezi döneminde aktif olarak çalıştığını bildiğimiz bir gazeteciyle başlanmıştır. Bu süreçte pek çok gazeteciden ret cevabı alındığı için, görüşmeler iki seneye yakın bir süre zarfında tamamlanmıştır. Görüşülen gazetecilerin içerisinde, televizyon haberciliği/programcılığı, haber kanalı müdürlüğü/editörlüğü, gazete editörlüğü, muhabirlik, köşe yazarlığı ve ombudsmanlık görevlerinde bulunmuş gazeteciler yer almaktadır. Muhabirlikten yöneticiliğe kadar çeşitli görevlerde çalışan gazetecilerle görüşme yapmış olmamız medya sektörünün her alanını anlamamız ve farklı bakış açılarını ele almamız açısından çalışmamıza fayda sağlamıştır. 
Yapmış olduğumuz görüşmelerde, gazetecilerden Gezi dönemindeki gazetecilik pratiklerini hem o dönemde çalıştıkları kurum (ya da öncesinde çalıştıkları kurum) hem de diğer medya kurumları açısından değerlendirmeleri istenmiştir. Gazetecilerin vermiş oldukları yanıtlar bağlamında onlara haber dili, elit/lider odaklı habercilik, gazetecilerin yeni medya kullanımı gibi konularda sorular yönlendirilmiştir. Görüşmenin sonunda gazetecilere barış gazeteciliğinin Türkiye'de gerçekleştirilebilmesinin önündeki engellerin neler olduğu ve bu engellerin aşılması, Türkiye'de daha iyi bir gazetecilik modeli geliştirilebilmesi ve/ veya barış gazeteciliği yapılabilmesi için ne gibi önerileri olabileceği sorulmuştur. ${ }^{9}$

$\mathrm{Bu}$ çalışmada Gezi dönemindeki habercilik pratikleri üzerine yapmış olduğumuz görüşmeler, gazetelerden elde etmiş olduğumuz veriler ile birlikte değerlendirilmiş ve barış gazeteciliği ekseninde nasıl bir dil kullanılması gerektiği ve nasıl bir habercilik yapılması gerektiği soruları tartışılmıştır.

\section{Gazetelerde Kullanılan Haber Dili, Bulgular ve Değerlendirme}

Eleştirel söylem analizi disiplinler üstü bir yaklaşım sunmaktadır. Teun van Dijk'ın belirttiği üzere, söylem analizi bir yandan metin ve konuşma yapıları arasındaki ilişkiyi açıklarken, diğer yandan bu yapıların bilişsel, toplumsal, kültürel ya da tarihsel bağlamlarına açıklama getirmektedir (1991, s. 110-111). Bu nedenle söylemin toplumsal ve kültürel işlevini kavrayabilmek için çalışmamızda eleştirel söylem analizi yöntemi kullanılmıştır.

Van Dijk'ın eleştirel söylem analizi yöntemine göre, haber metinleri makro ve mikro olmak üzere iki düzeyde çözümlenebilmektedir. Makro yapılar tematik ve şematik olmak üzere iki boyutta incelenmektedir. Tematik analizde, söylem hiyerarşik bir düzen içerisinde ana başlık (manşet), üst başlık (sürmanşet), başlık, alt başlık, spotlar, haber giriş metinleri, haber metinleri şeklinde, şematik analizde ise durum ve yorum incelenmektedir. Durum, habere konu olan olayın kim ve/ veya ne hakkında olduğunun, nerede olduğunun, ne zaman gerçekleştiğinin ve ne zaman haber olarak verildiğinin yani haberin hikâye örgüsünün incelenmesidir. Yorum ise habere konu olan kimselerin yapmış olduğu yorumların ve haberin kaynaklarının incelenmesi anlamına gelmektedir. Mikro düzeyde yapılan incelemeyi ise; kelime seçimleri, cümle yapıları, haberin kip ve zaman olarak incelenmesi, cümleler arasındaki ilişkiler ve haberin retoriği yani sayı, fotoğraf, resim gibi ikna edici öğelerin kullanımının analizi oluşturmaktadır (1988, s. 3059). Buradan yola çıkarak, çalışmamız kapsamında gazetelerin ilk sayfalarında yer alan Gezi ile ilgili haberlerde; manşet, sürmanşet, alt başlıklar, spotlar, ve haber giriş metinleri de dahil olmak üzere, kullanılan kelimeler ve kelime öbeklerine ilişkin frekanslar belirlenmiştir. Gazetelerin kullandıkları yaygın söylemlerin belirlenmesi, gazetenin yayın politikasının belirlenmesi açısından son derece önemlidir. Elde etmiş olduğumuz frekanslar bizim bir gazetenin Gezi'yi eylem,

9 Bu çalışma tamamlanmak üzere olan doktora tezimizin alan araştırmasına dayanılarak üretilmiştir. 
protesto ve/veya gösteri olarak mı, yoksa provokasyon, olay, işgal veya direniş ${ }^{10}$ olarak mı gördügünü anlamamızı sağlamaktadır.

Haberin gazetelerde yer alma biçiminin yanı sıra haberin ulaștığı kitlede bıraktığı etki, yani sonrası, haberin aktarılış biçimi kadar önemlidir. Van Dijk'ın (2006) ifade ettiği üzere söylemsel manipülasyon 'bizim iyi şeylerimiz' ile 'onların kötü şeyleri'nin vurgulanması ile gerçekleşmektedir. Bu nedenle, haber metni analiz edilirken medyanın ideolojik işlevinden ve söylemin ideolojiden ayrı düşünülemeyeceğinden yola çıkmak gerekmektedir. van Dijk eleştirel haber analizi yapılırken kullanılan en güçlü semantik kavramlardan bir tanesinin söylemin saklı anlamı yani 'ima' olduğunu belirtmektedir. Zira, metinde kullanılan kelimeler, cümleler ve metinsel ifadeler, arka plan bilgisine dayanan düşünceleri/görüşleri ya da önermeleri ima edebilmektedir (1991, s. 113-14). Bu bağlamda gazetelerin ilk sayfalarındaki kelime frekansları ve öbekleri belirlenirken gazetelerin kullanmış oldukları dil üzerinden ideolojik olarak nerede durduklarının kolaylıkla anlaşıldığı gözlemlenmiştir. Dolayısıyla kullanım frekansı düşük olmasına rağmen bazı kelimelerin ve/veya kelime öbeklerinin saklı anlamları dolayısıyla gazetelerde kullanılmış olmasının dahi, söylemin bağlamı açısından önem arz ettiği düşünülerek gazeteler için hazırlamış olduğumuz tablolarda, süreç boyunca bir veya iki kez kullanılan kelime ve/veya kelime öbeklerine tabloların ilgili satırlarında yer verilmiştir. Örneğin bir gazetenin Gezi'de eylem yapan insanları provokatör ya da militan olarak tanımlaması onun ideolojik duruşunu gösterdiği gibi bir başka gazetenin bu insanları halk, yurttaş ve/veya direnişçi olarak betimlemesi o gazetenin duruşunu göstermektedir. Bununla birlikte bir gazetenin "eylemci" kelimesini tek başına sıfatsı olarak vermesi ile eylemci kelimesinin başına "sözde" sıfatını ekleyerek "sözde eylemci" olarak vermesi veya "çevreci eylemci" kavramını kullanarak "çevreci olmayan eylemciler" olduğunu ima etmesi de gazetenin Gezi'ye bakışını göstermektedir. Tablolarda bir kelimenin ve/veya kelime öbeğinin kaç günde kaç defa kullanıldığı gösterilmektedir. Kelimelerin/kelime öbeklerinin bir kaç gün boyunca gündemde olan bir kavram olduğu için sıkça kullanılıp kullanılmadığının anlaşılması için tablolarda frekanslar ile birlikte ilgili söylemin kullanıldığı gün sayıSı da verilmiştir. Aynı frekans ve gün sayısına sahip kelime ve kelime öbekleri aynı satırda toplanmıştır.

Van Dijk söylem yoluyla toplumsal denetim uygulanmasının önemli koşulunun, söylemin denetiminin ve bizzat söylemin üretiminin olduğunu ifade etmektedir (2005, s. 319). Bu minvalde medyanın ideoloji inşa etme sürecinde iktidar sahiplerinden bağımsız bir şekilde hareket etmediğini söylemek gerekmektedir. Söylemlerin ideolojiler, bilgi, toplumsal kavrayış vb. işlemler ile ortaya çıktığını ve yeniden üretildiklerini ifade eden van Dijk (2010), medyaya, parlamenter tartışmalara ya da bilimsel sorgulamalara spesifik bir şekilde erişim

10 Sadece Gezi'yi tanımlamak amacıyla kullanılan 'eylem', 'direniş', 'protesto' 'gösteri' vb. kelimeler sayılmıştır. Örneğin "Taksim Meydanı'nda eylem yapıldı." vb. söylemlerde yer alan kelimeler ve direkt olarak bir kişinin ağzından çıkan ifadeler büyük puntolar ile başlıklarda yer almadığı sürece frekanslara dahil edilmemiştir. 
imkânına sahip kimselerin, bağlam üzerinde egemenlik kurmanın yanı sıra söylemin ana konularını da belirlediğini ifade etmektedir. Bu şekilde insanlar manipüle edilebilmektedir.

Gezi döneminde, özellikle Gezi'nin ilk günlerinde toplumun haber alma hakkının ihlal edilmiş olması söylemin ve söylemin üretiminin denetlendiğini bizlere göstermektedir. Gazetelerin bir bölümü Gezi'ye ilişkin haberleri ilk günlerde görmemeyi tercih ederken bir bölümü ilk günden itibaren Gezi'yi görmüştür. Aşağıda yer alan tabloda 29-30-31 Mayıs tarihlerinde gazetelerin Gezi ile ilgili haberlere ilk sayfalarında yer verip vermedikleri görülmektedir.

Tablo 1. 29-30-31 Mayıs tarihlerinde gazetelerin ilk sayfalarında Gezi

\begin{tabular}{|l|l|l|l|}
\hline Gazeteler & 29 Mayıs 2013 & 30 Mayıs 2013 & 31 Mays 2013 \\
\hline Akşam & X & V & V \\
\hline Birgün & V & V & V \\
\hline Cumhuriyet & V & X & V \\
\hline Habertürk & X & V & X \\
\hline Hürriyet & V & V & V \\
\hline Milliyet & V & X & V \\
\hline Posta & V & V & V \\
\hline Radikal & V & V & V \\
\hline Sabah & X & X & V \\
\hline Sözcü & V & X & X \\
\hline Star & X & X & V \\
\hline Taraf & V & V & V \\
\hline Yeni Akit & X & X & X \\
\hline Yeni Şafak & X & X & V \\
\hline Zaman & V & V & \\
\hline
\end{tabular}

Tabloda görüldüğü üzere Yeni Şafak ve Star 29-30-31 Mayıs tarihlerinde, Sabah, Yeni Akit ve Habertürk ise bu üç günlük sürenin ikişer gününde Gezi ile ilgili haberlere ilk sayfalarında yer vermemiştir. 30 Mayıs tarihinde Yavuz Sultan Selim Köprüsü'nün temel atma töreni gerçekleşmiş olduğu için Gezi gazetelerin ilk sayfalarında ya çok küçük yer almış ya da köprünün temel atma töreninin gölgesinde kalarak hiç yer bulamamıştır. Özetle özellikle hükümete yakın gazetelerin Gezi'nin ilk günlerini görmezden geldiği görülmektedir. Bu durum hem gazetecilik mesleki kodları açısından hem de barış gazeteciliği açısından uygun değildir. Gazetecinin en temel görevi kamunun bilgi edinme hakkını sağlamaktır. 
Haberler medya, iktidar, ideoloji ve sermaye ağı bağlamında nasıl üretilmekte ve konumlanmaktadır? Bu soru bizi lider odaklı habercilik üzerine düşünmeye yönlendirmektedir. Yapmış olduğumuz analizler sırasında Nvivo programı kullanılarak, Gezi'ye ilişkin haberler ile ilgili görsellerin kapladığı alanlar ve bu dönemde ismi çok geçen siyasi liderlerin fotoğraflarının ${ }^{11}$ kapladığı alanlar ayrı ayrı hesaplanmıştır ve liderlere atfedilen haber değeri üzerine bir takım veriler elde edilmiştir. Fotoğraflardan elde etmiş olduğumuz bu verilere göre Gezi'ye ilk sayfasında en çok yer ayıran gazete Radikal, en az yer ayıran gazete ise Yeni Akit'tir.

Grafik 1. Gezi'ye Illişkin Haberlerin Oranları

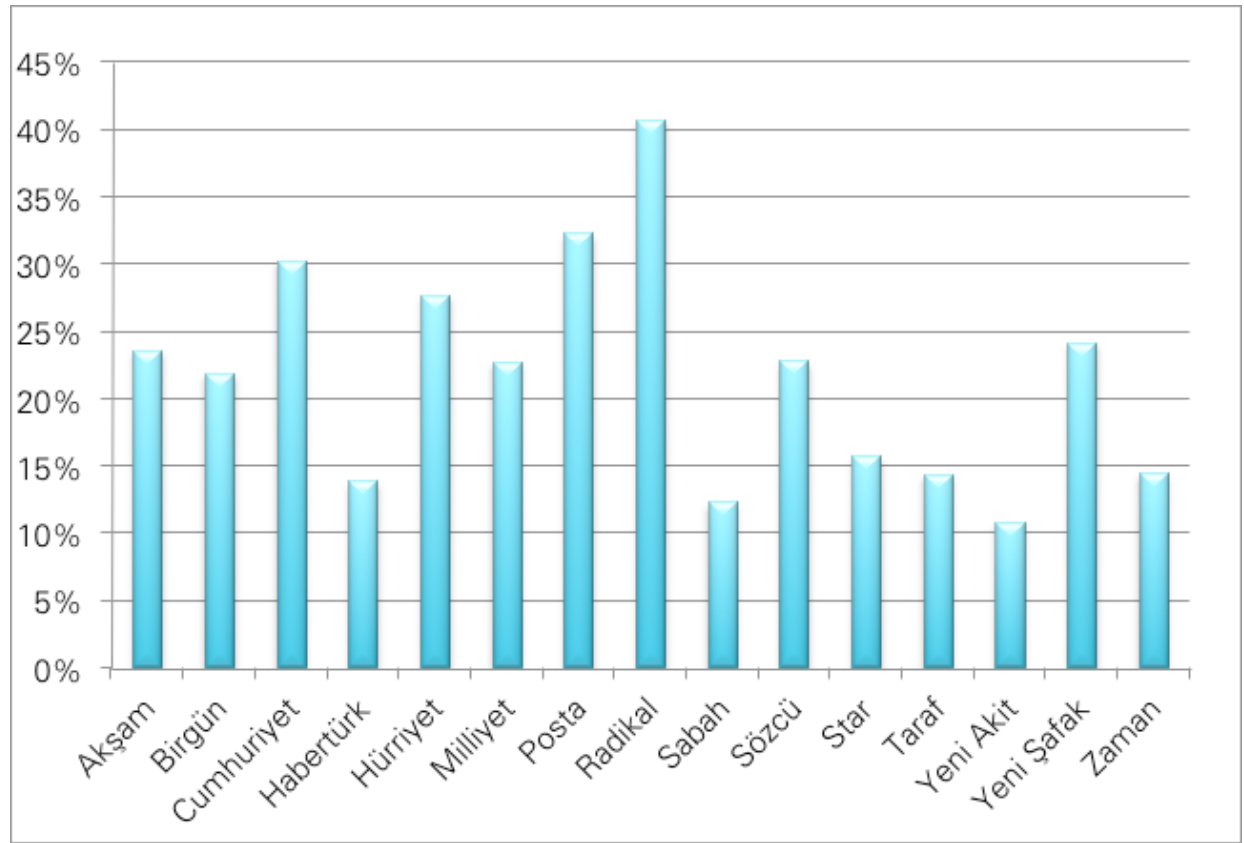

Bu bağlamda siyasi lider fotoğrafları da dahil olmak üzere tüm görsellerin ve buna bağlı olarak haberlerin kapladığı alana ilişkin sıralamanın büyükten küçüğe doğru; Radikal, Posta, Cumhuriyet, Yeni Şafak, Akşam, Sözcü, Milliyet, BirGün, Star, Zaman, Taraf, Habertürk, Sabah, Yeni Akit şeklinde olduğu görülmektedir. Aynı şekilde o dönemde gazetelerde yer alan siyasi liderlerin fotoğraflarının

11 Manşetin, haber başlıklarının, alt başlıkların, fotoğrafların ve haber metinlerinin, gazetelerin ilk sayfalarının mizanpajında iç içe geçmiş olduğu ve bazen Gezi ile ilgili olmayan bir haber ile ortak bir alanı paylaşabildiği görülmüştür. Gazetelerde haberler çoğunlukla kullanılan görsellerin üzerinden verilmiştir. Bu sebeple hem gezi haberlerine ilişkin alanlar hem de liderlerin söylemlerinin bulunduğu ve onların görsellerinin kullanıldığı haberlere ilişkin alanlar, sağlıklı bir veri elde edilmesi için fotoğraflar üzerinden hesaplanmıştır. 
alanları ve bu alanların tüm fotoğraflara olan yüzdeleri de hesaplanmıştır. Bütün gazetelerde en çok görseli kullanılan lider dönemin başbakanı Erdoğan olmuştur. Erdoğan'ı sırasıyla, Abdullah Gül (dönemin Cumhurbaşkanı), Bülent Arınç (dönemin Başbakan Yardımcısı), Kemal Kılıçdaroğlu (Ana Muhalefet Partisi-CHP Lideri), Hüseyin Avni Mutlu (dönemin İstanbul Valisi), Sırrı Süreyya Önder (Barış ve Demokrasi Partisi-BDP milletvekili), Kadir Topbaş (İstanbul Büyükşehir Belediyesi Başkanı), Devlet Bahçeli (Milliyetçi Hareket Partisi Lideri) ve Muammer Güler (dönemin İç İşleri Bakanı) izlemiştir. Selahattin Demirtaş'ın (BDP Eş Başkanı) ise Gezi döneminde Gezi'den ziyade 'barış süreci'ne yönelik yapmış olduğu açıklamalar ve haberler ile gazetelerde yer aldığı görülmektedir. Elde etmiş olduğumuz veriler doğrultusunda, Gezi'ye ilişkin haberlerde kullanılan görselleri en çok alan kaplayan lider Recep Tayyip Erdoğan'dır. Erdoğan'ı Abdullah Gül izlemektedir. On beş gazetenin tamamında yer alan görsellere ilişkin değerler toplandığında, Erdoğan'a ait görsellerin alanının Abdullah Gül'e ait görsellerden yaklaşık olarak yedi kat daha fazla olduğu görülmektedir. Buradan hareketle Erdoğan'a ilişkin haberlerin Gezi dönemindeki yaygın haber dilinde son derece etkili olduğunu söylemek yerinde olacaktır. Zira gazetelerde yer bulan haberlerde sıklıkla kullanılan 'çapulcu', 'faiz lobisi', 'rant', 'yabancı ajanlar', 'provokatör', 'terör örgütü', 'illegal/yasadışı örgüt' gibi söylemler Erdoğan'ın konuşmalarında kullandığı söylemlerdir. Bu sebeple Erdoğan'ın söylemlerinin gündemi belirlemiş olduğu görülmektedir. Tüm gazeteler içerisinde Gezi ile ilgili haberler ile Erdoğan'ın söylemlerine ilişkin haberler karşılaştırıldığında, Erdoğan'a ait görsellerin en çok yer kapladığı gazete Sabah'tır (tüm haberlerin \%41,58'i). Sabah, Gezi'ye ilişkin en az haber yapan ikinci gazete olmasına rağmen orantısal olarak bakıldığında en fazla lider görseli Sabah tarafından kullanılmıştır. Sabahı Star $(\% 37,79)$ ve Habertürk $(\% 22,92)$ takip etmektedir. Erdoğan'a en az yer veren gazeteler ise sırasıyla Cumhuriyet (\%0,72), Posta (\% 7.85) ve Radikal'dir (\% 7,94).

Lider fotoğraflarının ve söylemlerinin özellikle hükümete yakın gazeteler tarafından son derece fazla kullanılmış olması özellikle iktidara yakın gazetelerin halk/toplum odaklı değil, lider odaklı habercilik yapmış olduğunu bir kez daha kanıtlamaktadır. Tüm gazeteler içerisinde en az lider görseli kullanan gazetenin ise Gezi'ye ilişkin en çok haber yapan gazetelerden bir tanesi olan seküler, sol görüşlü Cumhuriyet gazetesi olduğu görülmektedir.

Elde etmiş olduğumuz tüm bu veriler ve haber dili üzerine elde etmiş olduğumuz frekans tabloları gazetelerin Gezi'deki duruşlarına ilişkin daha açık ve net bilgiler içermektedir. Gezi döneminde hükümete yakın gazetelerin kullanmış oldukları dildeki benzerlik son derece net bir şekilde görülmektedir. Yeni Şafak, Yeni Akit, Star, Sabah gazetelerinin ve o dönemde hükümete yakın olan Zaman'ın illegal/yasadışı örgüt, provokatör, provokasyon, ajan, militan, terörist, terör örgütü, vandalist/vandalizm, faiz lobisi gibi kavramları sık kullandıkları görülmektedir. Bunun yanı sıra muhafazakar, İslamcı bir gazete olan Yeni Akit'in sözde eylemci, sözde çevreci, yabancı ajan, bira lobisi vb. kelime öbekleri üreterek diğer 
gazetelere oranla daha ayrıştırıcı ve nefrete çağrı yapan bir dil kullandığı tespit edilmiştir. Aynı şekilde muhafazakar gazeteler olan Starve Yeni Şafakgazeteleri de Yeni Akit'e oldukça yakın bir dil kullanmıştır. Star'ın yayınladığı ve sonradan ortaya çıkan görüntü kayıtlarında gerçeği yansıtmadığı görülen "Kabataş olayına" ilişkin haber, başörtülü kimseye saldıran Gezi eylemcileri merkezli olması sebebiyle son derece ayrıştırıcıdır. Aynı şekilde Yeni Akit'in ve Yeni Şafak'ın da din kaynaklı bir çatışma ortamını körükleyen benzer haberleri kullandığı görülmektedir.

Tablo 2. Star kullanılan kelimeler, kelime öbekleri ve frekansları

\begin{tabular}{|l|l|l|}
\hline STAR & GÜN SAYISI & KELIME FREKANSI \\
\hline eylem & 16 & 25 \\
\hline eylemci & 11 & 17 \\
\hline gösterici & 8 & 11 \\
\hline faiz lobisi & 4 & 10 \\
\hline Gezi Parkı Olayları & 5 & 10 \\
\hline provokatör & 6 & 10 \\
\hline marjinal grup & 4 & 8 \\
\hline yasadış/illegal örgüt/grup & 4 & 7 \\
\hline gösteri & 6 & 6 \\
\hline çevreci & 2 & 5 \\
\hline duran adam eylemi & 2 & 4 \\
\hline militan & 2 & 3 \\
\hline protesto, provokatif eylem & 3 & 3 \\
\hline çevre duyarlıı̆ı/çevre kaygısı & 2 & 2 \\
\hline provokasyon, vandalizm & 1 & 2 \\
\hline $\begin{array}{l}\text { çevre eylemi, işgal, marjinal sol, marjinal temizlik, } \\
\text { protestocu, provokatif, rant, şiddet ve vandallıkla 'isyan } \\
\text { çıkarmak' isteyen eylemciler, şiddet yanlısı örgüt, terör } \\
\text { örgütü }\end{array}$ & 1 & 1 \\
\hline
\end{tabular}


Tablo 3. Yeni Akit kullanılan kelimeler, kelime öbekleri ve frekansları

\begin{tabular}{|c|c|c|}
\hline YENI AKIT & GÜN SAYISI & FREKANS SAYISI \\
\hline eylemci & 20 & 40 \\
\hline eylem & 16 & 33 \\
\hline Taksim/Gezi Parkı Olayları & 16 & 33 \\
\hline provokatör & 17 & 31 \\
\hline marjinal grup/sol grup/örgüt & 10 & 12 \\
\hline ajan & 4 & 12 \\
\hline çapulcu & 7 & 9 \\
\hline çevreci, faiz lobisi & 4 & 8 \\
\hline provokasyon & 5 & 6 \\
\hline provoke eden/provoke etmek & 4 & 4 \\
\hline işgal & 3 & 3 \\
\hline $\begin{array}{l}\text { ajan provokatör, illegal örgüt, marjinaller, tatlı rant, terör } \\
\text { örgütleri }\end{array}$ & 2 & 3 \\
\hline $\begin{array}{l}\text { Gezi Parkı provokasyonu, gösteri, gösterici, rant, sözde } \\
\text { çevreci }\end{array}$ & 2 & 2 \\
\hline bira lobisi, dış mihrak, sözde eylemci & 1 & 2 \\
\hline $\begin{array}{l}\text { alkol ve rant lobisi, aşırı uçlar, CHP ve marjinal kuyrukları, } \\
\text { iki yüzlü çevreciler, çevreci olduğunu iddia eden eylem- } \\
\text { ciler, duran adam eylemi, faiz-içki ve reklam çetesi, Gezi } \\
\text { Parkı hadisesi, Gezi Parkı lobisi, hükümet karşıtı eylem, } \\
\text { hükümeti devirme eylemi, illegal eylem, kaos eylemleri, } \\
\text { marjinal çevreler, marjinal güç, provokatif eylemler, provo- } \\
\text { katif gruplar, provokatif marjinal yapılanmalar, provokatif } \\
\text { olaylar, provokatif paylaşım, provokatif söylemler, rantiye, } \\
\text { sanal terör platformu, siber provokatör, sözde eylem, } \\
\text { spekülatör, terör yandaşları, terörist eylem, provokatif } \\
\text { adaletsiz }\end{array}$ & 1 & 1 \\
\hline
\end{tabular}


Tablo 4. Yeni Şafak kullanılan kelimeler, kelime öbekleri ve frekansları

\begin{tabular}{|l|l|l|}
\hline YENi ŞAFAK & GÜN SAYISI & KELIME SAYISI \\
\hline eylem & 22 & 161 \\
\hline eylemci & 18 & 44 \\
\hline Taksim/Gezi Parkı Olayları & 15 & 23 \\
\hline gösterici & 13 & 19 \\
\hline Gösteri & 12 & 18 \\
\hline provokatör & 6 & 11 \\
\hline faiz lobisi & 8 & 10 \\
\hline protesto & 8 & 10 \\
\hline illegal-yasadışı örgüt & 5 & 7 \\
\hline provokasyon & 4 & 7 \\
\hline marjinal/radikal grup & 6 & 6 \\
\hline çevre eylemi/çevreci eylem & 4 & 5 \\
\hline protestocu & 2 & 4 \\
\hline ajan & 1 & 4 \\
\hline provoke eden/provoke etmek & 3 & 3 \\
\hline provokatif mesajlar & 2 & 2 \\
\hline çevreci, militanlar, oturma eylemi, vandallar & 1 & 2 \\
\hline $\begin{array}{l}\text { çevre duyarlılı̆ı, duran adam eylemi, isyan, maskeli } \\
\text { grup, sokakları karıştıran eylemler, sivil şiddetsiz darbe } \\
\text { girişimi, twitter örgütü, vatandaş, şiddet eylemleri, şiddete } \\
\text { dönüşen eylemler, ranta dönüşturen yatıımcılar, Gezi } \\
\text { rantcıları, provokatif eylem, provokasyona dönüşen eylem }\end{array}$ & 1 & 1 \\
\hline
\end{tabular}

Sabah'ın haberi çoğunlukla görmemeyi tercih ettiği, gördüğü zaman ise büyük oranda Erdoğan'ın söylemleri üzerinden gördüğü dikkat çekmektedir. Gezi döneminde hem Gülen Cemaati'ne hem de iktidara yakınlığı ile bilinen muhafazakar bir gazete olan Zaman gazetesi12 ise diğer gazetelere oranla hükümete olan mesafesini biraz daha fazla korumuş ve haberi aktarırken daha yalın bir dil kullanmayı tercih etmiştir.

12 İstanbul 6. Sulh Ceza Hakimliği, Zaman gazetesini de bünyesinde bulunduran Feza Gazetecilik şirketine "şirketin Fetullahçı Terör Örgütü/Paralel Devlet Yapılanması'nın (FETÖ/PDY) faaliyetleri kapsamında ve örgüt faaliyetlerine destek olacak şekilde kullanıldığı yönünde kuvvetli deliller bulunması" gerekçesiyle, 4 Mart 2016 tarihinde kayyum atanması kararı almıştır. 
Tablo 5. Sabah kullanılan kelimeler, kelime öbekleri ve frekansları

\begin{tabular}{|l|l|l|}
\hline SABAH & GÜN SAYISI & KELiME SAYISI \\
\hline eylem & 8 & 16 \\
\hline gezi parkı olayları & 9 & 12 \\
\hline eylemci & 6 & 11 \\
\hline faiz lobisi & 4 & 5 \\
\hline gösterici & 3 & 3 \\
\hline çıkar lobisi, provokatör & 2 & 2 \\
\hline $\begin{array}{l}\text { çapulcu, çevreci, direniş, duran adam eylemi, illegal- } \\
\text { yasadışı örgüt, işgal, marjinal grup, protesto, provokasyon, } \\
\text { provokatör örgüt, provoke eden örgütler, terör örgütü, } \\
\text { vandalizm }\end{array}$ & 1 & 1 \\
\hline
\end{tabular}

Tablo 6. Zaman kullanılan kelimeler, kelime öbekleri ve frekansları

\begin{tabular}{|l|l|l|}
\hline ZAMAN & GÜN SAYISI & KELIME SAYISI \\
\hline eylem & 21 & 60 \\
\hline eylemci & 16 & 39 \\
\hline gösterici & 10 & 23 \\
\hline gezi parkı olayları & 11 & 16 \\
\hline marjinal grup & 7 & 12 \\
\hline protesto & 7 & 12 \\
\hline gösteri & 4 & 7 \\
\hline çevresel/çevreci eylem & 4 & 4 \\
\hline provokasyon & 3 & 4 \\
\hline şiddet eylemi & 3 & 3 \\
\hline provokatör & 2 & 3 \\
\hline protestocu & 2 & 2 \\
\hline çevreci örgüt & 1 & 2 \\
\hline $\begin{array}{l}\text { ajan, çevreci eylemci, duran adam eylemi, provokatif, pro- } \\
\text { vokatif eylem, siyasi gösteri, terör örgütü, vatandaş }\end{array}$ & 1 & 1 \\
\hline
\end{tabular}

Habertürk'ün de haberi hükümete daha yakın bir dil ile ele aldığı görülmektedir. Gazetenin merkezi Gezi Parkı'na yürüme mesafesinde olmasına karşın, Habertürk 29 ve 31 Mayıs tarihlerinde Gezi'yi ilk sayfasında görmemiş, 30 Mayıs'ta ise çok küçük yer vermiştir. 1 Haziran'da ise Başbakan Erdoğan'ın söylemleri üzerinden haberi vererek "Başbakan konuştu Taksim açıldı" başlığını kullanmıştır. Gazetenin genel yayın yönetmeni Fatih Altaylı'nın Erdoğan ile yapmış 
olduğu Teke Tek Özel programına ilişkin haber geniş bir şekilde manşetten verilirken programın ardından gazete önünde eylemcilerin medyayı protesto etmesi gazetenin ilk sayfasında yer bulamamıştır. Özetle gazetenin çoğunlukla lider odaklı habercilik yaptığı görülmektedir.

Tablo 7. Habertürk kullanılan kelimeler, kelime öbekleri ve frekansları

\begin{tabular}{|l|l|l|}
\hline HABERTÜRK & GÜN SAYISI & KELIME FREKANSI \\
\hline eylem & 18 & 28 \\
\hline eylemci & 11 & 24 \\
\hline Gezi Parkı Olayları & 4 & 5 \\
\hline duran adam eylemi & 4 & 4 \\
\hline gösterici & 3 & 3 \\
\hline direniş & 2 & 2 \\
\hline $\begin{array}{l}\text { ajan, chapulling, eylem meydanı, faiz lobisi, gösteri, } \\
\text { militan, protesto, sivil toplum hareketi }\end{array}$ & 1 & 1 \\
\hline
\end{tabular}

$\mathrm{Bu}$ gazetelerin yanı sıra kullanmış oldukları söylemlerin bağlamı düşünüldüğünde belirli bir ideolojik duruşa sahip olduğu açıkça gözlemlenen BirGün, Taraf, Sözcü ve Cumhuriyet gazetelerinin kullandıkları kelimeler ve kelime öbekleri de oldukça ilgi çekicidir. Sosyalist, sol bir gazete olan BirGün, öngörülebileceği üzere Gezi'de bulunan insanları çoğunlukla 'direnişçi', Gezi'yi ise 'direniş' olarak betimlemiştir. Gezi sırasında yapılan haberlerde ağırlıklı olarak eylemin doğasına ve amacına yönelik haberler yapılmasını tercih etmişler ve yaratıcı ve esprili bir dil kullanarak "Taksim Gaz Parkı", "Çapulcunun el kitabı" gibi başııklar kullanmışlardır. Hükümete yakın medya tarafından sıklıkla kullanılan, dönemin başbakanı Erdoğan'ın 'faiz lobisi', 'dış mihrak' gibi söylemlerini kendi üsluplarınca esprili bir şekilde ele almışlardır. Bunun yanı sıra sesini duyurmak isteyen eylemcilerin sesine haberlerde yer vermişlerdir. Gezi'de hayatını kaybeden ve yaralananlar ile ilgili haberler ilk sayfadan verilmiştir. Ancak gazetenin ilk sayfasında yer alan haberlerde hükümet ve Tayyip Erdoğan ağır bir dille eleştirilmiştir. 'Devlet terörü', 'diktatör', 'faşizan uygulama', 'faşizm', 'polis terörü', 'polis şiddeti' gibi söylemler haberlerde çokça kullanılmıştır. Barış gazeteciliğine göre 'terör' gibi toplumu ayrıştırıcı ve şiddeti çağrıştıran kavramların kullanılması konusunda özellikle hassas davranılması gerekmektedir. Zira 'terör' gibi kelimelerin sık kullanılması 'terör' kavramını insanların kulaklarına yerleştirmekte ve bu kavramın daha normal ve olağan bir şeymiş gibi anlaşılmasına neden olmaktadır. Bu sebeple BirGün'de yer alan haberler barış gazeteciliği perspektifiyle incelendiğinde haberlerde sesi duyulmayanın sesine yer verildiği için barış gazeteciliği prensiplerine uyulmakta olduğu ancak yer yer ayrıştırıcı ve çatışmacı bir dil kullanılması sebebiyle barış gazeteciliği prensiplerine uyulmadığı görülmektedir. 
Tablo 8. BirGün kullanılan kelimeler, kelime öbekleri ve frekansları

\begin{tabular}{|l|l|l|}
\hline BiRGÜN & GÜN SAYISI & KELIME FREKANSI \\
\hline direniş & 25 & 113 \\
\hline halk & 15 & 50 \\
\hline eylemci & 17 & 37 \\
\hline çapulcu & 14 & 25 \\
\hline eylem & 18 & 25 \\
\hline polis terörü & 8 & 18 \\
\hline yurttaş & 8 & 16 \\
\hline direnişçi & 11 & 14 \\
\hline polis şiddeti & 8 & 13 \\
\hline isyan & 8 & 10 \\
\hline faiz lobisi & 4 & 7 \\
\hline Gezi Parkı Olayları & 6 & 7 \\
\hline protesto & 4 & 6 \\
\hline duran insan/adam eylemi & 2 & 5 \\
\hline diktatör & 4 & 4 \\
\hline gösteri & 3 & 4 \\
\hline devlet terörü, faşizm, rant & 3 & 3 \\
\hline dış mihrak, eylem alanı & 1 & 2 \\
\hline gösterici, protesto gösterisi, protestocu & 2 & 2 \\
\hline direnenler, faşizan uygulama, finans lobisi, halk direnişi, \\
halk isyanı, halk protestosu, işgal, provokatör & 1 & 1 \\
\hline
\end{tabular}

Cumhuriyet de BirGün gibi kendisine has bir dil kullanmıştır. Gazetede yer alan haberlerin çoğunda aynı BirGün'de olduğu gibi mağdurların ve eylemcilerin sesine yer verilmiştir. Yani lider odaklı habercilikten kaçınılmıştır. Ancak Cumhuriyet de BirGün gibi eylem yapan kimseleri sadece eylemci, protestocu ve/veya gösterici olarak tanımlamamış, çoğunlukla halk, yurttaş ve direnişçi olarak tanımlamıştır. Söyleyecekleri bir sözleri olduğu için Gezi'de bulunan insanlar eylemci, protestocu kimlikleri ile orada bulunmaktadırlar. Bu sebeple Gezi döneminde yaşanan çatışmalar sadece halk ile devlet ve onun baskı aygıtları arasında yaşanmamıştır. Gezi döneminde yaşananlar ifade ve eylem özgürlüğünü kullanarak toplumun farklı kesimlerinden, halktan insanlar ile devlet ve onun baskı aygıtları arasında yaşanmıştır. Dolayısıyla Gezi'de bulunan insanları sadece toplumsal kimlikleri üzerinden değil, aynı zamanda orada bulunma nedenleri üzerinden tanımlamak daha doğru bir yaklaşım olacaktır. 
Tablo 9. Cumhuriyet kullanılan kelimeler, kelime öbekleri ve frekansları

\begin{tabular}{|l|l|l|}
\hline CUMHURIYET & GÜN SAYISI & KELIME FREKANSI \\
\hline eylem & 21 & 46 \\
\hline direniş & 20 & 44 \\
\hline eylemci & 19 & 37 \\
\hline yurttaş & 16 & 29 \\
\hline gösterici & 9 & 19 \\
\hline çapulcu & 13 & 18 \\
\hline direnişçi & 10 & 14 \\
\hline halk & 9 & 13 \\
\hline polis şiddeti & 7 & 11 \\
\hline protesto & 8 & 9 \\
\hline gösteri & 7 & 7 \\
\hline duran adam eylemi & 4 & 5 \\
\hline faiz lobisi & 2 & 4 \\
\hline protesto gösterisi & 3 & 3 \\
\hline halk direnişi, halk hareketi, isyan, polis terörü & 2 & 2 \\
\hline protestocu & 1 & 2 \\
\hline $\begin{array}{l}\text { Gezi Parkı direnişi hareketi, halk eylemi, provokatör, } \\
\text { provoke etmeye çalışan iktidar }\end{array}$ & 1 & 1 \\
\hline
\end{tabular}

Liberal bir gazete olan Taraf da tıpkı BirGün ve Cumhuriyet gibi haberlerinde mağdurların ve eylem yapan kişilerin sesine yer vermiştir. BirGün ve Cumhuriyet kadar çok olmamakla birlikte eylem yapan kişileri bazı haberlerinde vatandaş, halk ve direniş̧̧i olarak tanımlamıştır. Taraf ta yer alan haberlerde de yaratıcı söylemlerin olduğu görülmektedir. Örneğin, İstanbul dışından gelen ve 5 gün boyunca parkta yatan polislere ilişkin haber verilirken polis ve çapulcu kelimeleri birleştirerek 'çapulis' kelimesini yaratmışlardır. Esprili bir dil ile verilen bu haberde aslında yaratıcı bir üslup ile polisin mağduriyeti aktarımaktadır. 
Tablo 10. Taraf kullanılan kelimeler, kelime öbekleri ve frekansları

\begin{tabular}{|l|l|l|}
\hline TARAF & GÜN SAYISI & KELiME SAYISI \\
\hline eylem & 18 & 53 \\
\hline eylemci & 13 & 20 \\
\hline direniş & 13 & 15 \\
\hline protesto & 11 & 12 \\
\hline çapulcu & 6 & 8 \\
\hline Gezi Parkı Olayları & 6 & 7 \\
\hline gösterici & 6 & 6 \\
\hline duran insan eylemi & 3 & 5 \\
\hline vatandaş, gösteri & 4 & 4 \\
\hline sivil direniş & 3 & 3 \\
\hline ajan, halk, isyan & 2 & 3 \\
\hline Çapul TV & 1 & 3 \\
\hline direnişçi, protestocu & 2 & 2 \\
\hline $\begin{array}{l}\text { chapulling, çapulis, çevreci, duran insanlar örgütü, faiz lo- } \\
\text { bisi, halk hareketi, protesto eylemleri, protesto gösterisi, } \\
\text { provokasyon, sivil itaatsizlik, Taksim Hareketi }\end{array}$ & 1 & 1 \\
\hline
\end{tabular}

Atatürkçü ve ulusalcı bir gazete olan Sözcü de eylem yapan insanların ve mağdurların seslerine yapmış olduğu haberlerde yer vermiştir. Ancak haberleri verirken 'Halka işkence ve zulmün fotoğrafları' gibi şiddet çağrışımı yapan başlıkları kullanmaktan kaçınmamıştır. Duran insan eylemleri gerçekleşirken, bir tam sayfada duran insanlara söz hakkı vererek neden durdukları sorulmuştur. Eylem yapan kimseleri çoğunlukla 'halk' olarak tanımlayan gazete, hükümete yakın olan gazetelerin kullandıkları dili onlara karşı kullanarak 'marjinal dinciler' diye bir söylem oluşturmuştur. Zaman zaman esprili bir dil kullanan gazetenin, yapmış olduğu haberlerde çoğunlukla 'onlar've 'biz' ayrımına gittiği görülmektedir. Gazetede yer alan haberlerde o dönemde PKK ve BDP ile yürütülen 'barış süreci'ni eleştiren bir üslup kullanıldığı görülmektedir. Örneğin, Gezi sırasında BDP milletvekili olan Sırrı Süreyya Önder'in konuşma yaptığı bir fotoğrafın altında 'Taksim Meydanı bunlara kaldı' başlığı kullanılmıştır. Sözcü gazetesinde halkın sesine yer verilen haberler bulunmasına rağmen, gazetenin kullanmış olduğu çatışmacı dil sebebiyle barış gazeteciliği prensiplerinden oldukça uzakta konumlandığı görülmektedir. 
Tablo 11. Sözcü kullanılan kelimeler, kelime öbekleri ve frekansları

\begin{tabular}{|l|l|l|}
\hline SÖZCÜ & GÜN SAYISI & KELIME FREKANSI \\
\hline halk & 17 & 51 \\
\hline eylemci & 15 & 39 \\
\hline eylem & 17 & 30 \\
\hline vatandaş & 11 & 15 \\
\hline direniş & 9 & 14 \\
\hline protesto & 11 & 12 \\
\hline çapulcu & 7 & 11 \\
\hline gezi olayları & 7 & 8 \\
\hline çevreci & 2 & 5 \\
\hline duran adam/insan eylemi & 2 & 5 \\
\hline protestocu & 4 & 5 \\
\hline gösterici & 3 & 4 \\
\hline marjinal grup/eylemci & 1 & 4 \\
\hline AKP militanları & 2 & 3 \\
\hline direnişçi, terörist muamelesi & 3 & 3 \\
\hline marjinal & 2 & 3 \\
\hline PKK'lı teröristler & 1 & 3 \\
\hline APO-PKK yandaşları, halk hareketi & 1 & 2 \\
\hline faiz lobisi, rant lobisi & 2 & 2 \\
\hline $\begin{array}{l}\text { diktatör, gezi'ci, hak arayan millet, marjinal dinciler, pro- } \\
\text { desto eylemi, protesto gösterisi, provokatör, sivil toplum } \\
\text { direnişi, yurttaş }\end{array}$ & 1 & 1 \\
\hline
\end{tabular}

Sol bir gazete olan Radikal gazetesi13 incelendiğinde, ilk sayfalarının neredeyse tamamının Gezi'ye ayrıldığı görülmektedir. Çoğunlukla büyük görseller kullanan gazete, ilk sayfasında az sayıda yazılı haber kullanmıştır. Bu sebeple ilk sayfalarının analizleri sonucunda elde etmiş olduğumuz kelime frekansları çok anlamlı sonuçlar doğurmamaktadır. Gezi'yi bir çevre ve şehir hareketi olarak gören gazete, 29-30-31 Mayıs tarihlerinde Taksim Yayalaştırma Proje üzerine yapılan tartışmalara değinmiş ve alternatif projeler üzerine haberler vermiştir. 1 Haziran'da ise 'Ne bu şiddet bu celal' başığı ile Taksim'deki şiddetli müdahaleyi gösteren tam sayfa bir fotoğraf kullanarak şiddeti eleştiren bir haber yapmıştır. Sonraki günlerde sağduyu mesajları içeren haberler yapan gazete hem politik

13 Doğan Yayın Grubu'na ait olan Radikal gazetesi 21 Haziran 2014 tarihinde dijital yayıncılığa geçmiştir. 22 Mart 2016 tarihinde ise internet sitesinin de kapatılması ile yayın hayatına son verilmiştir. 
liderlerin hem de eylemcilerin olduğu haberlere ve fotoğraflara yer vermiştir. Gazete, olanı olduğu gibi verdiği için ve Gezi'nin çevre hareketinden toplumsal bir harekete dönüşmesini gösterdiği için barış gazeteciliği adına iyi bir örnek sergilemektedir.

Tablo 12. Radikal kullanılan kelimeler, kelime öbekleri ve frekansları

\begin{tabular}{|l|l|l|}
\hline RADiKAL & GÜN SAYISI & KELIME SAYISI \\
\hline eylem & 11 & 17 \\
\hline eylemci & 8 & 12 \\
\hline duran adam eylemi & 2 & 5 \\
\hline direniş & 3 & 4 \\
\hline lobi & 2 & 3 \\
\hline Gezi Parkı Olayları & 2 & 2 \\
\hline isyan & 2 & 2 \\
\hline $\begin{array}{l}\text { aktivist, çapulcu, direnişci, halk, işgal, marjinal, protesto, } \\
\text { terörist }\end{array}$ & 1 & 1 \\
\hline
\end{tabular}

Türkiye'nin en çok okunan gazetelerinden olan Posta ${ }^{14}$ Gezi ile ilgili haberleri detaylı bir şekilde ele almıştır. Mağdurların ve eylemcilerin sesine yer veren gazete, Gezi'ye dair haberleri, yapılan yoga derslerinden kılınan Cuma namazına kadar her detayı gösteren fotoğraflar ile haberleştirmiştir. Bunun yanı sıra gazete siyasi liderlerin söylemlerine ilişkin haberlere de yer vermiştir. Gezi'ye giden ünlü isimleri de ilk sayfadan veren Posta, Gezi'ye magazinsel bir şekilde de değinmiştir. Tüm bunların yanı sıra gazete eylem yapan kimseleri sadece eylemci olarak değil aynı zamanda halk ve vatandaş olarak da tanımlamıştır. Gezi boşaltıldıktan sonraki günlerde gazetenin ambleminin üzerinde ağılıklı olarak kadın bedenini metalaştıran görseller kullanarak magazin haberleri verdiği görülmektedir. 19 Haziran tarihinde Gezi'ye ilişkin bir ifadenin yer aldığı bir magazin haberinde, haberin içeriği ile ilgisi olmamasına rağmen söylemi üreten kişinin mayolu bir resmi kullanılmıştır.

14 Posta'nın 27 Mayıs 2013, 3 Haziran 2013, 10 Haziran 2013 ve 17 Haziran 2013 haftalarındaki tiraj rakamları incelendiğinde, gazetenin Zaman gazetesinden sonra en çok tiraja sahip gazete olduğu yani en yüksek tirajı ikinci gazete olduğu görülmektedir. Bu tarihlerdeki geçmiş dönem tiraj bilgilerine link üzerinden erişilebilir; http://www.canlitv.com/rating/?tur=gazete\&tarih=2013-05-27 
Tablo 13. Posta kullanılan kelimeler, kelime öbekleri ve frekansları

\begin{tabular}{|l|l|l|}
\hline POSTA & GÜN SAYISI & KELIME FREKANSI \\
\hline eylem & 24 & 81 \\
\hline eylemci & 17 & 31 \\
\hline halk & 10 & 24 \\
\hline gösterici & 7 & 18 \\
\hline direniş & 12 & 15 \\
\hline Gezi Parkı Olayları & 11 & 15 \\
\hline direnişçi & 6 & 10 \\
\hline duran adam eylemi & 4 & 10 \\
\hline gösteri & 8 & 10 \\
\hline vatandaş & 3 & 4 \\
\hline faiz lobisi & 1 & 3 \\
\hline protesto eylemleri, provokatör & 2 & 2 \\
\hline yasadışı grup/örgüt & 1 & 2 \\
\hline çapulcu, halk direnişi, isyan, marjinal teyze, sivil hareket & 1 & 1 \\
\hline
\end{tabular}

Ana akım gazetelerden Hürriyet, Milliyet ve sağ görüşe sahip Akşam gazeteleri hem eylemcilere hem de iktidarın söylemlerine yer veren haberler yapmışlardır. Hürriyet de Posta gibi çok sayıda görsel kullanmıştır. Protestoların ilk günlerinde liderlerden ziyade eylemcilerin sesinin daha çok duyulduğu haberlere daha fazla yer ayıran gazete, sonraki günlerde gerçekleştirilen milli irade mitinglerini de geniş bir şekilde ele almıştır. Yaralanan ve hayatını kaybeden kimselere ilişkin haberlere ilk sayfasında yer ayıran gazetenin, bazı haberlerinde halkın ve Gezi'dekilerin sesine yer verdiği, bazı haberlerinde ise iktidara yakın bir söylem kullandığı görülmektedir.

Tablo 14. Hürriyet gazetesi kullanılan kelimeler, kelime öbekleri ve frekansları

\begin{tabular}{|l|l|l|}
\hline HÜRRIYET & GÜN & KELIME SAYISI \\
\hline eylemci & 20 & 41 \\
\hline eylem & 20 & 39 \\
\hline protesto & 14 & 24 \\
\hline gösterici & 7 & 12 \\
\hline Gezi Parkı Olayları & 10 & 11 \\
\hline duran adam & 3 & 9 \\
\hline gösteri & 8 & 8 \\
\hline protestocu & 5 & 8 \\
\hline
\end{tabular}




\begin{tabular}{|l|l|l|}
\hline çapulcu & 3 & 4 \\
\hline direniş & 3 & 3 \\
\hline gezi sakinleri, vatandaş & 2 & 2 \\
\hline $\begin{array}{l}\text { aktivist, çapullamak, çevreci, direnişçi, gezi parkı } \\
\text { ayaklanması, marjinal gruplar, provokasyon, provokatör, } \\
\text { saldırgan grup, şiddet gösterisi }\end{array}$ & 1 & 1 \\
\hline
\end{tabular}

Milliyet gazetesi mağdurlara ve eylemlere ilişkin çok sayıda görsele ve habere geniş bir şekilde yer vermiştir. Bununla birlikte gazete, çalışanlarının Gezi'de olduğunu gösteren görselleri kullanarak yazarlarının görüşlerine yer verdiği haberler de gazetenin ilk sayfasında bulunmaktadır. Bu haberlerin yanı sıra hükümete yakın medyada görülen bir takım haberler ve söylemler de gazetede görülmektedir. Örneğin; Gezi Parkı'ndan sökülen ağaçların başka bir parka ekildiğine ilişkin bir habere gazetede yer verilmiştir.

Tablo 15. Milliyet kullanılan kelimeler, kelime öbekleri ve frekansları

\begin{tabular}{|l|l|l|}
\hline MiLLiYET & GÜN SAYISI & KELIME FREKANSI \\
\hline eylem & 24 & 80 \\
\hline eylemci & 18 & 28 \\
\hline protesto & 14 & 19 \\
\hline gösterici & 12 & 18 \\
\hline Gezi Parkı Olayları & 11 & 14 \\
\hline protestocu & 9 & 11 \\
\hline direniş & 6 & 8 \\
\hline duran adam eylemi & 3 & 6 \\
\hline gösteri & 5 & 5 \\
\hline faiz lobisi & 3 & 4 \\
\hline çapulcu & 2 & 3 \\
\hline halk & 1 & 2 \\
\hline çevreci, direnenler, isyan, rant, toplumsal hareket & 1 & 1 \\
\hline
\end{tabular}

Akşam 29 Mayıs'ta Gezi ile ilgili haberlere ilk sayfasında yer vermemiştir. Sonraki günlerde ise ilk etapta 'direniş', 'direnişçi', 'halk' gibi kelimeleri kullanan gazetenin, başbakanın açıklamaları ve milli irade mitingleri ile devam eden süreçte, özellikle park boşaltıldıktan sonra bu kelimeleri kullanmadığı (sadece bir kez 'direniş' kelimesi kullanılmıştır) ve söylem değiştirdiği görülmektedir. İlk günlerde Gezi'de bulunan insanlara ve eylemlere ilişkin pek çok habere yer veren gazete, sonraki günlerde siyasilerin görüşlerini ve milli irade mitinglerini geniş bir şekilde ele almıştır. 
Tablo 16. Akşam kullanılan kelimeler, kelime öbekleri ve frekansları

\begin{tabular}{|l|l|l|}
\hline AKŞAM & GÜN SAYISI & FREKANS SAYISI \\
\hline eylem & 18 & 53 \\
\hline eylemci & 22 & 51 \\
\hline Gezi Parkı Olayları & 13 & 27 \\
\hline gösterici & 9 & 20 \\
\hline protesto & 12 & 15 \\
\hline direniş & 7 & 8 \\
\hline gösteri & 6 & 7 \\
\hline faiz lobisi & 3 & 6 \\
\hline protestocu & 4 & 5 \\
\hline provokasyon & 4 & 4 \\
\hline vatandaş & 3 & 3 \\
\hline $\begin{array}{l}\text { çapulcu, direnişçi, gezi'ci, halk, illegal örgüt, protesto } \\
\text { gösterisi }\end{array}$ & 2 & 2 \\
\hline capul residans, marjinalleşmek & 1 & 2 \\
\hline $\begin{array}{l}\text { çapulcular partisi, çevreci, duran adam eylemi, eylem } \\
\text { alanı, halk eylemi, marjinal grup, pasif direniş, terör } \\
\text { örgütü }\end{array}$ & 1 & 1 \\
\hline
\end{tabular}

Tablolardan anlaşılacağı üzere sadece haberin verilmesi toplumsal uzlaşmanın sağlanması konusunda yeterli değildir. Özellikle merkez medyada konumlanan gazetelerin Gezi'ye çok fazla yer ayırmış olmalarına karşın Gezi'de bulunan insanların, grupların, sivil toplum örgütlerinin seslerine ilk sayfalarında yeterince yer vermedikleri görülmektedir ve bu durum bu gazetelerin sermaye ve iktidar arasındaki konumları sebebiyle nasıl haber yapmaları gerektiği konusunda endişe duydukları izlemini yaratmaktadır. Hükümete yakın medya kuruluşlarının ise manipülatif, insanları kimlikleri (yabancı ajan gibi) üzerinden yargılayarak nefret söylemi oluşturan, hedef gösteren (Memet Ali Alabora'nın tiyatro oyununun hükümete yakın medyada Gezi'ye hazırlık olarak tanımlanmasında olduğu gibi) bir dil kullandığı görülmektedir. Nefret içerikli, hedef gösteren ve yargılayıcı nitelemelerin kullanıldığı haberler çatışmaya ve şiddete hizmet etmektedir.

Haberin yapılması kadar haberin nasıl yapıldığı da son derece önemlidir. Sesi çıkmayanın sesi olmak, haberde çatışmanın tüm taraflarına alt kırılımları ile yer vermek son derece mühimdir (örneğin feminist örgütler niçin Gezi'ye destek verdi? Cumartesi Anneleri, Anti Kapitalist Müslümanlar, LGBTi örgütler neden Gezi'deydi?). Gezi her şeyden önce elinde BDP bayrağı olan bir eylemcinin, elinde Atatürk posterli Türk bayrağı taşıyan bir eylemciyi TOMA'nın sıktığı sudan çekerek uzaklaştırdığı sırada bir başka eylemcinin güvenlik güçlerine bozkurt işareti yaptığını gösteren fotoğrafta olduğu gibi çok sesli bir harekettir. 
Dolayısıyla haberlerde Gezi'ye dahil olan tüm bu kesimlerin sesine yer vermek gerekmektedir ${ }^{15}$. Bu noktada gazetecilerin bir çatışmayı sadece görünür etkileri açısından değerlendirmemesi gerektiğine, haberlerde çatışmanın bağlamının ve niteliğinin de ele alınması gerektiğine vurgu yapmalıdır.

\section{Gazetecilerin Haber Dili Üzerine Görüş ve Önerileri}

Söz konusu verileri gazetecilerin haber dili üzerine olan görüşleri ve önerileri üzerinden analiz etmek Türkiye'deki gazetecilerin barış gazeteciliğine bakışlarını değerlendirmemiz açısından son derece önemlidir.

Gazetecilere barış gazeteciliğinin önündeki en önemli sorunların neler olduğu sorulduğunda, görüşmüş olduğumuz gazetecilerin \%73'ü (22 gazeteci) haberlerde çatışmacı ve ayrımcı bir dil kullanıldığına vurgu yapmıştır.

Bunun yanı sıra gazetecilerin çoğu açık veya dolaylı bir şekilde medya kuruluşları tarafından iktidarın dilinin benimsenmiş olduğunu belirtmişlerdir. Erdoğan tarafında kullanılan 'çapulcu' kavramı bunun en renkli örneklerinden bir tanesidir. Zira hem hükümete yakın medya kuruluşları hem de hükümete yakın olmayan medya kuruluşları bu kavramı, birbirinden taban tabana zıt anlamlarla kullanmışlardır.

Milliyet gazetesi ombudsmanı Belma Akçura devletin tehdit algılamaları neyse basının onu bir tehdit algılaması gibi kamuoyuna sunduğunu ifade etmektedir. O dönemde Star gazetesinde çalışan Doğan Ertuğrul medya kuruluşlarının almış oldukları pozisyonları Erdoğan'ın ifadelerinin belirlediğini dile getirmektedir. Radikal gazetesi muhabiri İsmail Saymaz, bazı medya kuruluşlarında çalışan kimselerin ruh olarak Gezi'de olduklarını ancak çıkarttıkları ürünler bağlamında iktidarın yanında konumlandığı belirterek medya, iktidar ve sermaye ilişkisinin ideoloji üzerindeki etkisine vurgu yapmaktadır.

Gezi döneminde CNN Türk'ün genel yayın yönetmenliğini yapan Rıdvan Akar, iktidarın dil üzerindeki etkisini 'barış süreci' ile değişen dil üzerine vermiş olduğu bir örnek ile açıklamaktadır. Akar, 'barış'kavramının, PKK ve devlet arasında çatışmaların yaşandığı son 30 yıl içerisinde PKK tarafından devlet politikalarının anti-tezi olarak kullanıldığını söyleyerek, bu nedenle kavramın kullanımının, kavramı kullananın otomatikman PKK'lı olarak algılanmasına neden olduğunu belirtmiştir. AKP hükümetinin algı operasyonlarını çok iyi yürüttügünü ifade eden Akar, barış sürecinde üretilen haberlerde "Öcalan'ın İmralı, barışın ise çözüm" olarak yer aldığının altını çizmiş ve konjonktür ve yaşanan atmosferdeki değişimin aslında haber dilinin değişmesi ve yumuşaması için gerekli olan imkanları bizlere sağladığını söylemiştir.

15 Fotoğraf Doğan Haber Ajansı (DHA) foto muhabiri Uğur Can tarafından13 Haziran günü polisin Gezi'ye müdahalesi sırasında Taksim Meydanı'nda çekilmiştir. 
Saldırgan bir dilin kullanılması Cumhuriyet gazetesinden Deniz Ülkütekin'in de ifade ettiği gibi birtakım negatif sonuçlar doğurabilmektedir. Ülkütekin söylemlerin insanları psikolojik olarak yıpratma ile alakalı olduğunu dile getirerek, bunun topluma ciddi zararlar verebileceğini ifade etmektedir. Gezi'de bir sürü insanın hayatını kaybetmesinin nedeninin de biraz da o söylemlerin sonucu olduğunu söylemektedir. Ülkütekin'in düşüncelerinden yola çıkarak psikolojik bir savaşın fiziksel kayıplara yol açabildiğini söylemek yanlış olmayacaktır. Dolayısıyla medya kuruluşlarının toplumu ayrıştıran ve şiddeti meşru kılan söylemlerin negatif sonuçları olabileceğini öngörerek bu söylemlerden kaçınması gerekmektedir.

Peki Gezi bir eylem midir? Direniş midir? Protesto mudur? Yoksa bir provokasyon veya olay mıdır? Kelime frekanslarına baktığımızda BirGün'ün Gezi'yi çoğunlukla direniş olarak tanımladığı görülmektedir. Gezi'de yer alan eylemciler ise çoğunlukla direnişçi olarak betimlenmiştir. Gazetenin o dönemdeki yazı işleri müdürü Barış İnce, Gezi konusunda bir taraf olduklarını ve o sebeple Gezi'yi direniş olarak tanımladıklarını ifade etmektedir. Gezi döneminde haklının yanında olmaya ve insanların haklarını korumaya çalıştıklarını ifade eden Ince, zaman zaman kullandıkları dilin sertleştiğini ve zaman zaman Tayyip Erdoğan'a karşı BirGün'ün de ona yakın bir dil kullandığı anlar olduğunu söylemiştir. Bununla birlikte söz konusu haberlerin o günkü şartlarda ele alınması gerektiğini belirtmektedir. Gazetecinin de öfkelenen, ağlayan ya da Ali İsmail öldüğünde acı çeken bir insan olduğuna vurgu yapan İnce, gazetecinin bir robot olmadığını söyleyerek taraf olması gerektiğini belirtmektedir. İnce bunu yaparken makul insanlar olarak, Erdoğan'a destek veren insanların, onları anlaması için bu insanların anlayacakları bir dil kullandıklarını ifade etmektedir. 'Biz de babaannemizi zor tutuyoruz' diye bir başlık attıklarını söyleyen İnce, bu başlık ile 'biz terörist değiliz biz babaannesinin dolma yedirdiği çocuklarız aslında' demek istediklerini ifade etmiştir.

Barış gazeteciliği perspektifi ile İnce'nin ifadelerini ele aldığımızda, bir kez daha BirGün'ün Gezi dönemindeki yayın politikasının barış gazeteciliği ile hem çelişen hem de paralel düşen yanları olduğu görülmektedir. Her şeyden önce barış gazeteciliği doğası nedeniyle gazetecinin mağdurdan yana olması gerektiğini ifade etmektedir. Ancak haber yapılırken kullanılan kelimelerin yalın ve çatışmadan uzak kelimeler olması son derece önemlidir. Sesi duyulmayan kişilerin seslerinin daha fazla duyulmasını sağlamak için gazetenin de daha fazla okunması gerekmektedir. Nitekim, kendisini gazetenin söyleminin tamamen karşısında konumlandıran insanlar gazetenin kullanmış olduğu dili kendisine bir saldırı olarak algılayarak gazetenin hak haberciliği konusunda atmış olduğu olumlu adımları da görmeyebilir. Dolayısıyla yapılan haberlerin kitlelere ulaşmasını sağlamak için kullanılan dile özen göstermek gerekmektedir.

Gezi, direniş olarak tanımlandığında okurda sol görüşe yönelik bir algı oluşmaktadır. Gezi, provokasyon, hükümete karşı eylem vb. şekillerde tanımlandığında ise hükümete yakın muhafazakar gazetelere yönelik bir algı ortaya çıkmaktadır. Gazetecilere Gezi'yi nasıl tanımlamamız gerektiği sorulduğunda 
haber dilinde Gezi'nin ne ise o olarak tanımlanması gerektiği yönünde cevaplar gelmiştir. Eylem ise eylem, protesto ise protesto olarak tanımlanmalıdır.

Yeni Akit gazetesinden Murat Alan ise Gezi'ye direniş denildiğinde Gezi'nin kriminalize bir anlamı olduğunu ifade etmektedir. Toplumun Gezi konusunda önünde sonunda ikiye ayrılacağını ifade eden Alan bir kısım insanın buna darbe diyeceğini bir kısmın ise buna direniş diyeceğini ifade ederek Gezi'ye protesto diyen çok az kişi kalacağını söylemektedir. Alan'ın söylemleri barış gazeteciliği bağlamında ortak bir dil oluşturmanın mümkün olmadığı algısının oluşmasına sebep olmaktadır. Ancak barış gazeteciliği çatışma çözümünde her zaman bir orta yolun bulunabileceğini ifade etmektedir.

Gezi döneminde Sabah gazetesinin ombudsmanlığını yapan Yavuz Baydar, haber dili konusunda Gezi'nin betimlenmesinin biraz zor olduğunu ifade ederek, Gezi'nin aslında sosyal, kültürel bir direniş olduğunu söylemiş ve bunun arkasında kürtaj olduğunu, 1 Mayıs'ın engellenmesi olduğunu, Emek Sineması olduğunu, içki yasağının olduğunu, Ankara metrosundaki öpüşme yasağının olduğunu belirtmiş̧tir. Haber dilinde ise Gezi'nin eylemden ziyade protesto olarak tanımlanması gerektiğine vurgu yapmıştır.

Gezi döneminde Taraf'ta çalışan, Cumhuriyet gazetesi yazarlarından Ceyda Karan, olanın 'protesto, eylem, işgal, direniş' ne ise öyle tanımlanması gerektiğini ifade etmiştir. Dünyaca ünlü kuruluşların el kitaplarında haber dili üzerinde durulduğunu ve haberlerde etiketlerden kaçınmak gerektiğini ifade etmiştir. Bu bağlamda Gezi'deki grupların 'teröristler, çapulcular, darbeciler' diye normalde haber dilinde olmayan ifadeler ile tanımlanmasını eleştiren Karan, bu konuda uluslararası kriterlerin çok net olduğunu belirterek, eylem ise eylemci denilmesi gerektiğinin altını çizmiştir. Direnişçi gibi ifadelerin Gezi'de bulunan kimselerin kendilerine atfettikleri bağlamda, dolaylı olarak kullanılması gerektiğini söyleyen Karan, dil konusunda her zaman nötr ifadeler bulunabileceğine vurgu yapmıştır.

Taraf'tan Ertan Altan Gezi'ye bilinçli olarak direniş dediklerini ifade etmiştir. Direniş denildiği zaman taraf olunduğunu söyleyen Altan, yabancı basının, BBC'nin bunu, Gezi Protestoları diye yansıttığını söyleyerek, gazetecilik açısından doğru tanımının da 'protesto' olduğunu belirtmiştir. Ertan, protestolar sırasında siyasal olarak kutuplaşıınca medyanın da kutuplaştığını ve medyanın taraflarının da bu dile savrulduğunu belirterek, iktidarın Gezi'yi 'darbe girişimi' olarak değerlendirmesine karşı onların da Gezi'yi 'direniş' olarak değerlendirdiğini söylemiştir.

Hürriyet gazetesinin ombudsmanı Faruk Bildirici de Ceyda Karan gibi olan ne ise tanımlamanın o şekilde yapılması gerektiğini belirterek, propagandist içerikler taşımadığı sürece, Gezi'dekilerin söylediklerini kullanmak gerektiğini, böylece o eylemin içerisindeki ya da o aktivitenin içerisindeki kişilere yabancılaşmadan onları anlama konusunda bir adım atılmış olacağını ifade etmiştir. Bildirici, Hürriyet'te de genellikle o şekilde 'eylemci' ve 'eylem' olarak kullanıldığını söylemiştir. 
Görüşme yaptığımız gazetecilerin görüşlerini genel olarak ele aldığımızda çoğunun Gezi'yi protesto ve eylem olarak tanımlanmasının doğru olduğu yönünde ifadeler kullandığı görülmektedir. Haberlerde kullanılan kelime frekanslarına baktığımızda 'eylem' kelimesi en çok kullanılan kelime olarak karşımıza çıkmaktadır. Öte yandan Barış İnce'nin ifadesiyle kendilerini taraf olarak tanımladıkları için, BirGün'ün diğer gazetelerden farklılaştığı ve 'direniş' ifadesini daha çok kullandığı tespit edilmiştir. Uluslararası medyanın ifade ettiği şekilde 'Gezi Parkı Protestoları' kullanımı ise diğer tüm kullanımlara göre oldukça düşük bir frekanstadır. Gezi'de bulunan ya da eylemlerin birer parçası olan insanlar ise çoğunlukla 'eylemci', 'protestocu' ve/veya 'gösterici' olarak tanımlanmaktadır. BirGün, Cumhuriyet, Sözcü ve Posta gazetelerinin bu ifadelerin yanı sıra 'halk', 'yurttaş' ve 'vatandaş' gibi ifadeleri kullanmış oldukları görülmektedir. Yeni Akit, Star, Yeni Şafak ve Zaman gazetelerinin ise çeşitli sıfatlar ile eylem vb. kelimeleri 'provokatif eylem', 'sözde eylem' vb. kelime öbeklerine dönüştürdügü ve 'eylem' kelimesine başka anlamlar yüklediği görülmektedir. Bunun yanı sıra 'Gezi Parkı Olayları' ifadesine ise özellikle hükümete yakın gazeteler tarafından sıklıkla yer verildiği görülmektedir.

Elde etmiş olduğumuz verilerden hareketle, Türkiye'de kelimelere olduklarından daha farklı anlamlar yüklendiğini söylemek mümkündür. Bu noktada gazetecilerin çoğunun haber dilinde kullanılmasının uygun olacağını söylediği 'eylem' ve 'protesto' kelimelerinin anlamlarına bakmak gerekmektedir. TDK'da 'eylem' kelimesi "bir durumu değiştirme ve daha ileriye götürme yönünde etkide bulunma çabası" olarak tanımlamaktadır. 'Protesto' ise "bir davranışı, bir düşünceyi, bir uygulamayı haksız, yersiz, gereksiz bularak karşı çıkma, kabul etmeme" olarak tanımlamaktadır. Yeni toplumsal bir hareket olarak Gezi'nin hem protesto hem de eylem olarak betimlenmesi son derece yerindedir. Gezi en temelinde şehrin merkezinde bulunan bir parktaki ağaçların kesilmesi yönündeki bir uygulamaya karşı çıkılmasıyla başlayan bir toplumsal harekettir. $\mathrm{Bu}$ protestonun amacı ise mevcut durumu değiştirmektir. Nihayetinde Gezi, görüşmüş olduğumuz gazetecilerin pek çoğunun ifade ettiği şekilde, mevcut durumu değiştirmek adına gerçekleştirilen bütün eylemleri de içine alarak büyüyen bir harekete dönüşmüştür.

\section{Sonuç ve Öneriler}

George Orwell'in deyimiyle "Gazetecilik, birilerinin yayınlanmasını istemediği haberleri yazmaktır; gerisi halkla ilişkilerdir. "Söz konusu ifadeden yola çıkarak bir kez daha gazetecinin en temel görevinin kamunun bilgi edinme hakkını sağlamak olduğunu söylemek gerekmektedir. Ancak Gezi'nin ilk günlerinde iktidarın eleştirisine maruz kalacağını düşünen medya patronları, yöneticileri ve medya çalışanları haberi görmemeyi tercih etmişlerdir.

Kuşkusuz ki, Gezi Parkı'nda başlayan bu hareketin haber dilinde nasıl tanımlanacağına karar vermenin dahi bu denli zor ve karmaşık olduğu bir 
ortamda, haber yapmak son derece güçtür. Türkiye'de her kelimeye bir anlam yüklenmektedir ve kelimeleri bağlamıyla düşünen gazeteciler haberde kullandıkları söylemler dolayısıyla onlara yapıştırılabilecek etiketlerin uzun vadedeki etkilerinden çekinmekte ve oto-sansür ile yüzleşmektedirler. Bu nedenle haberlerin liderlerin söylemleri üzerinden aktarıldığı görülmektedir.

Hükümete yakın medya kuruluşları ayrıştırıcı ve kutuplaştırıcı söylemler ile manipülatif haberler üretirken, muhalif medya kuruluşları iktidara yakın medya kuruluşlarının kullanmış olduğu dile alternatif bir dil oluşturarak kendi ideolojileri çerçevesinde kendi üsluplarını kullanarak yer yer saldırgan söylemler kullanmışlardır. Bu nedenle barış gazeteciliği perspektifiyle Gezi haberlerinde kullanılan dile baktığımızda gazetelerin kötü birer sınav verdiği görülmektedir. Merkezde konumlanan ana akım medya kuruluşları ise kendilerini iktidarın söylemleri ile eylemcilere ilişkin haberler arasında bulmuşlar, ne haberi tam anlamıyla aktarabilmişler ne de hareketin doğasını anlamak yönündeki haberlere yeterince yer verebilmişlerdir.

Çalışmamızın ilk bölümünde yapmış olduğumuz kuramsal tartışmalardan ve araştırma verilerimize yönelik analizlerden hareketle; ideoloji, iktidar, sermaye ve medya arasındaki ilişkilerin haberin söylemini açık bir şekilde etkilediğini söyleyebiliriz. Araştırma verilerimizden de anlaşılacağı üzere gazetelerde kullanılan görseller, üretilen söylemler ve kelime frekansları hangi gazetenin iktidara ne kadar yakın olduğunu ve hangisinin ne kadar uzak olduğunu gözler önüne sermektedir.

Barış gazeteciliği bağlamında Türkiye şartlarında Gezi'yi ele aldığımızda ilk sayfalarında yer alan tüm haberler ile olmasa da belli başlı noktalarda bütün gazetelerin belirli konularda sınıfta kaldığı görülmektedir. Gandhi, "Barışa giden yol yoktur, barışın kendisi bir yoldur!" demiştir. Dolayısıyla haber yaparken barışın kendisinin bir yol olduğunu düşünerek o yoldan gitmek gerekmektedir. Barış yolundan ancak ve ancak etik, toplumun sesini dinleyen, çok sesli, sadece lider odaklı değil aynı zamanda toplum/insan odaklı, ifade özgürlüğüne ve kamunun haber alma özgürlüğüne duyarlı, nefret dilinden uzak durulan barış dilinin kullanıldığı bir habercilik yapılarak gidilebilir.

\section{Kaynakça}

Althusser L. (2003). İdeoloji ve Devletin İdeolojik Aygıtları. (A. Tümertekin Çev.). İstanbul: İthaki Yayınları.

Alankuş S. (2016). Barış Gazeteciliği El Kitabı. İstanbul: IPS İletişim Vakfı Yayınları. Balcı B. (12 Haziran 2013). Piyasaların Gezi Bilanços. Hürriyet. Erişim 29 Ocak 2016. http://www.hurriyet.com.tr/piyasalarin-13-gunluk-gezi-bilancosu-23489964 
Avrupa İnsan Hakları Sözleşmesi. Erişim 25 Kasım 2016. http://www.echr.coe. int/documents/convention_tur.pdf

Chomsky N. (2013). Occupy/lşsgal Et. İstanbul: Agora Kitaplığı.

Foucault, M. (1987). Söylemin Düzeni. (T. Ilgaz, Çev). İstanbul: Hil Yayınları.

Freedom House. (2013). Freedom of the Press 2013-Turkey. Erişim 29 Ocak 2016. https://freedomhouse.org/report/freedom-press/2013/turkey\#.VIT_2PI_u_Q

Freedom House. (2014a). Freedom of the Press 2014-Turkey. Erişim 29 Ocak 2016. https://freedomhouse.org/report/freedom-press/2014/turkey\#.VIT_ZfI_u_ Q

Freedom House. (2014b). Freedom On The Net 2014-Turkey. Erişim 29 Ocak 2016. https://freedomhouse.org/report/freedom-net/2014/turkey

Türkiye Gazeteciler Cemiyeti. (2013). Medya'da olağan üstü halin kalkmasını diliyoruz Erişim 29 Ocak 2016. http://www.tgc.org.tr/duyuru. asp?did=600

Galtung J. (2009). Çatışmaları Aşarak Dönüştürmek: Çatışma Çözümüne Giriş. (H. Kök Çev.). Ankara: USAK.

Gülcan E. (23 Ekim 2013, 2013a). Habercinin "Gezi"si: Saldırı, Gözaltı, İstifa, Isssizlik, Bianet Bağımsız Iletişim Ağı. Erişim 29 Ocak 2016. http://www.bianet. org/bianet/ifade-ozgurlugu/150722-habercinin-gezi-si-saldiri-gozalti-istifa-issizlik

Gülcan E. (10 Ekim 2013, 2013b). Habercinin üç aylık "Gezi Direnişi". Bianet Bağımsız Iletişim Ağı. Erişim 29 Ocak 2016. http://www.bianet.org/bianet/ifadeozgurlugu/150514-habercinin-uc-aylik-gezi-direnisi

Inceoğlu Y. ve Sözeri C. (2012). Nefret Suçlarında Medyanın Sorumluluğu: “Ya sev ya terk et ya da...". Yasemin İnceoğlu (der.) Nefret Suçları ve/veya Nefret Söylemi içinde (23-37). İstanbul: Ayrıntı Yayınları.

İrvan S. (2004). Barış Gazeteciliği, Erişim tarihi 29 Ocak 2016. http://globalmediatr.emu.edu.tr/bahar2006/Baris_Gazeteciligi/baris \% 20gazeteciligi. \% 20 s\%C3\%BCleyman\%20irvan.pdf

Keeble, R. L. (2010). Peace Journalism as political practice: A new radical look at theory, Keeble R. L., Tulloch J. \& Zollman F. (der.), Peace Journalism; war and Conflict Resolution içinde (49-67). New York: Peter Lang Publishing.

Lynch J. ve Galtung J. (2010). Reporting Conflict: New Directions in Peace Journalism: New Approaches to Peace and Conflict. Australia: University of Queensland Pr.

McGoldrick A. ve Lynch J. (2005). Peace Journalism. UK, Hawthorn Press \&The Cormwell Press.

Mitchell W. J. T., Harcourt B. E., Taussing M. (2013). İşgal Et: İtaatsizlik Üzerine Üç Tez. (E. Ersavcı, Çev.). İstanbul: Kolektif Kitap. 
Patindol J. L. C., (2010). Building a peace journalists' network from the ground: the Philippine experience, Keeble R. L., Tulloch J. \& Zollman F. (der.). Peace Journalism; war and Conflict Resolution içinde (193-205). New York: Peter Lang Publishing.

Shinar D. (2008), Bağımsız Medya ve Barış Gazeteciliği, Çelenk S. (ed.) Başka Bir Iletişim Mümkün Bildiriler Kitabı içinde. İstanbul: IPS İletişim Vakfı Yayınları.

Van Dijk T. A. (1988). News as a Discourse. Hilsdale/New Jersey: Lawrence Erlbaum Associates, Inc., Publishers.

Van Dijk T. A. (1991). Media Contents, the interdisciplinary study of news as discourse, Jensen K. B. \& Jankowski N.W.(der.)A Handbook of Qualitative Methodologies for Mass Communication Research içinde (108-120). London \& New York: Routledge.

Van Dijk T. A. (2005). Söylemin Yapıları ve İktidarın Yapıları. Mehmet Küçük (der.). Medya, iktidar, İdeoloji içinde (315-359). Ankara: Bilim ve Sanat.

Van Dijk T. A. (2006). Discourse and manipulation, Barcelona: Sage Publication.

Van Dijk T. A. (2010). Söylem ve İktidar, Ayşe Çavdar (ed). Nefret Suçları ve Nefret Söylemi içinde İstanbul: Hrant Dink Vakfı Yayınları.

Vardar N. (9 Ocak 2013). Sevda Alankuş Barış Gazeteciliği'ni anlatıyor. Bianet Bağımsız Iletişim Ağı. Erişim 29 Ocak 2016. http://bianet.org/bianet/ toplum/143409-sevda-alankus-baris-gazeteciligini-anlatiyor

Zizek S. (2013). Dünyadaki Issyanların Anlamı. (O. Akınay Çev.). İstanbul: Agora Kitaplığı.

Türkiye Gazetecileri Hak ve Sorumluluk Bildirgesi. Erişim 29 Ocak 2016. http:// www.tgc.org.tr/bildirge.asp

Sınır Tanımayan Gazeteciler. (2014). Dünya Basın Özgürlüğ̈̈ Indeksi. http://rsf. org/index2014/en-index2014.php

Türk Dil Kurumu, Büyük Türkçe Sözlük. Erişim 29 Ocak 2016. http://tdk.gov.tr/ index.php?option=com_bts\&view=bts 


\section{EK 1}

\section{Görüşmeler}

Barış Ince, 24.04.2015

Belma Akçura, 05.11.2015

Bülent Mumay, 24.04.2014

Ceyda Karan, 04.12.2015

Deniz Ülkütekin, 12.12.2014

Doğan Ertuğrul, 15.06.2015

Edda Sönmez, 29.09.2014

Elif İnce, 22.04.2014

Enver Aysever, 18.06.2014

Ertan Altan, 06.12.2015

Faruk Bildirici, 13.06.2015

Gökmen Ulu, 19.09.2014

Güngör Karakuş, 15.04.2015

Güray Öz, 27.11.2015

Işın Eliçin, 10.11.2015

İsmail Saymaz, 22.02.2014

Kürşat Bumin, 12.11.2015

Makbule Cengiz, 11.09.2014

Mehmet Kamış, 26.10.2015

Mehveş Evin, 29.09.2014

Mete Çubukçu, 22.04.2014

Murat Aksoy, 30.10.2015

Murat Alan, 23.04.2015

Murat Seçkin, 18.11.2015

Mustafa Alp Dağıstanlı 16.04.2014

Mustafa Hoş, 10.04.2015

Rıdvan Akar, 28.08.2014

Serkan Ocak, 14.05.2014

Yavuz Baydar, 09.04.2015

Zülfikar Ali Aydın, 15.04.2014 